\title{
Composite study of aerosol export events from East Asia and North America
}

\author{
Y. Luan and L. Jaeglé \\ Department of Atmospheric Sciences, University of Washington, Seattle, Washington, USA \\ Correspondence to: L. Jaeglé (jaegle@uw.edu)
}

Received: 30 July 2012 - Published in Atmos. Chem. Phys. Discuss.: 28 August 2012

Revised: 25 December 2012 - Accepted: 9 January 2013 - Published: 1 February 2013

\begin{abstract}
We use satellite observations of aerosol optical depth (AOD) from the Moderate Resolution Imaging Spectrometer (MODIS) together with the GEOS-Chem global chemical transport model to contrast export of aerosols from East Asia and North America during 2004-2010. The GEOSChem model reproduces the spatial distribution and temporal variations of Asian aerosol outflow generally well, although a low bias $(-30 \%)$ is found in the model fine mode AOD, particularly during summer. We use the model to identify 244 aerosol pollution export events from E. Asia and 251 export events from N. America over our 7-year study period. When these events are composited by season, we find that the AOD in the outflow is enhanced by 50-100\% relative to seasonal mean values. The composite Asian plume splits into one branch going poleward to the Arctic in 3-4 days, with the other crossing the Pacific Ocean in 6-8 days. A fraction of the aerosols is trapped in the subtropical Pacific High during spring and summer. The N. American plume travels to the northeast Atlantic, reaching Europe after 45 days. Part of the composite plume turns anticyclonically in the Azores High, where it slowly decays. Both the Asian and N. American export events are favored by a dipole structure in sea-level pressure anomalies, associated with midlatitude cyclone activity over the respective source regions. This dipole structure during outflow events is a strong feature for all seasons except summer, when convection becomes more important. The observed AOD in the E. Asian outflow exhibits stronger seasonality, with a spring maximum, than the N. American outflow, with a broad spring/summer maximum. The large spring AOD in the Asian outflow is the result of enhanced sulfate and dust aerosol concentrations, but is also due to a larger export efficiency of sulfate and $\mathrm{SO}_{2}$ from the Asian boundary layer relative to the N. American
\end{abstract}

boundary layer. While the N. American sulfate outflow is mostly found in the lower troposphere (1-3 km altitude), the Asian sulfate outflow occurs at higher altitudes $(2-6 \mathrm{~km})$. In the Asian outflow 42-59\% of the sulfate column is present above $2 \mathrm{~km}$ altitude, with only $24-35 \%$ in the N. American outflow. We link this to the factor of 2-5 lower precipitation in the warm conveyor belts (WCB) of midlatitude cyclones over E. Asia compared to N. America. This relative lack of precipitation makes Asian WCB very efficient for injecting aerosols in the middle troposphere.

\section{Introduction}

The long-range transport of aerosols from East Asia to the North Pacific Ocean and the North American west coast has been observed for several decades (e.g., Prospero, 1979; Duce et al., 1980; Andreae et al., 1988; Prospero et al., 2003; Jaffe et al., 1999, 2003; Arimoto et al., 1996, 1997; Husar et al., 2001; Clarke et al., 2001; VanCuren, 2003; Bertschi et al., 2004; Bertschi and Jaffe, 2005; Heald et al., 2006a; McKendry et al., 2008). Intensive field campaigns over the western and eastern Pacific Ocean have shown that Asian aerosols are a complex mixture of dust and anthropogenic particles, and contain significant levels of absorbing soot and organic carbon as a result of extensive coal burning and biomass burning (e.g., Hoell et al., 1996; Hoell et al., 1997; Jacob et al., 2003; Huebert et al., 2003; Parrish et al., 2004; Singh et al., 2009). Asian pollution layers intercepted 3-10 days downwind over the N. Pacific Ocean have elevated sulfate aerosol levels but reduced organics compared to measurements near the Asian continent (Andreae et al., 1988; Peltier et al., 2008; Dunlea et al., 2009; van Donkelaar et al., 2008). 
This is consistent with fast formation of sulfate and organic aerosols within 1-2 days of emission over the Asian continent, followed by washout during lofting, and then slower conversion of the modestly-soluble anthropogenic $\mathrm{SO}_{2}$ to sulfate aerosols during transport aloft (Brock et al., 2004). Export of Asian pollutants is strongest in spring, when the Asian aerosol plumes can be transported across the N. Pacific Ocean within a few days, but also occurs in other seasons (e.g., Liang et al., 2004; Holzer et al., 2005).

There is also significant observational evidence for longrange transport of N. American aerosols to the N. Atlantic and Europe. Polluted plumes of N. American origin have been sampled at several remote sites over the N. Atlantic Ocean (e.g., Parrish et al., 1998; Savoie et al., 2002; Benkovitz et al., 2003; Huntrieser et al., 2005; Millet et al., 2006; Owen et al., 2006). Aerosols in the N. American outflow are dominated by sulfate, with a significant contribution from organic carbon aerosols, especially during summer as a result of fires and biogenic precursor emissions (e.g., Millet et al., 2006; Murphy et al., 2006; Heald et al., 2006b; Goldstein et al., 2009). Aerosols from boreal forest fires over Alaska and Canada can be transported to Europe, influencing both the free troposphere and surface (Forster et al., 2001; Wandinger et al., 2004).

Lofting in the Warm Conveyor Belt (WCB) of midlatitude cyclones followed by rapid transport in the strong westerly winds is considered to be the major mechanism for longrange transport of pollution from East Asia (Yienger et al., 2000; Holzer et al., 2003, 2005; Liang et al., 2005; Wuebbles et al., 2007) and from N. America (Cooper et al., 2002; Stohl et al., 2002; Li et al., 2005). These WCBs are particularly active during spring, but play a major role in controlling long-range transport for all seasons (Liang et al., 2005; Li et al., 2005; Kiley and Fuelberg, 2006). In addition, transport in the boundary layer behind or ahead of the surface cold fronts of midlatitude cyclones is another pathway of pollution export at lower altitudes (Liu et al., 2003; Liang et al., 2004; Cooper et al., 2002). During summer, convective processes can also play an important role (Thompson et al., 1994; Bey et al., 2001a; Li et al., 2006; Kiley and Fuelberg, 2006). The efficiency with which aerosols and their precursors are transported in each of these pathways depends on how much dry and wet deposition they experience. Aerosols transported in the marine boundary layer close to the ocean's surface are rapidly removed by deposition. Rapid upward transport in midlatitude cyclones or convective storms is associated with intense precipitation. This leads to the scavenging of most pre-existing hydroscopic particles, resulting in a decrease of aerosol export efficiencies with altitude (Park et al., 2005). Pollution aerosols (which we will use to refer to a mixture of industrial/urban pollution aerosols as well as biomass burning aerosols) are thus most efficiently transported above the boundary layer between $900-700 \mathrm{hPa}$ (Bahreini et al., 2003; Huebert et al., 2003; Heald et al., 2006a). A study by Dickerson et al. (2007) found that dry convection, with little precip- itation, may be especially effective in the vertical transport of aerosols over NE China during spring. Furthermore, as warm air from the polluted continents advects over colder marine air, stable conditions with minimal vertical mixing can be produced (Angevine et al., 1996; Knapp et al., 1998). As a result the pollution layers are isolated from the ocean surface and soluble species, such as aerosols and nitric acid, can be transported hundreds of kilometers downwind at relatively low altitudes (Daum et al., 1996; Neiman et al., 2006; Owen et al., 2006).

Satellite observations present a global view of the distribution of aerosols and their precursors over multiple years, overcoming the limitation of in-situ measurements in duration and spatial coverage. While satellite observations have their own limitations (i.e., cloud contamination, limited information on aerosol type and/or vertical distribution of aerosols), they can be used to provide new evidence for the intercontinental transport of aerosols, and make the quantification of this transport flux possible. For example, Yu et al. (2008) used satellite observations from the Moderate Resolution Imaging Spectrometer (MODIS) and the Geoscience Laser Altimeter System (GLAS) to derive a $18 \mathrm{Tg}$ year $^{-1}$ flux of pollution aerosols leaving Asia (at $30-60^{\circ} \mathrm{N}$ ), $25 \%$ reaching the N. American west coast. Using both MODIS and the space-based lidar Cloud Aerosol LIdar with Orthogonal Polarization (CALIOP), Yu et al. (2012) found that $56 \mathrm{Tg}$ of dust reaches the west coast of N. America, such that the overall inflow of industrial/urban, biomass burning and dust aerosols to N. America is comparable to the total mass of aerosols emitted over N. America. Remote sensing observations from the Ozone Monitoring Instrument (OMI) and the Infrared Atmospheric Sounding Interferometer (IASI) show frequent transpacific transport of $\mathrm{SO}_{2}$ plumes from E. Asia (Li et al., 2010; Clarisse et al., 2011; Hsu et al., 2012).

A mechanistic understanding of the processes leading to export and long-range transport of pollution has come from studying individual case studies, in which specific transport plumes were observed by in situ instruments and/or by satellites over the N. Pacific and N. Atlantic Oceans (e.g., Stohl and Trickl, 1999; Jaffe et al., 1999, 2001, 2003; Cooper et al., 2001, 2004; Husar et al., 2001; Brock et al., 2004; Heald et al., 2006a; Dickerson et al., 2007; Eguchi et al., 2009). Validating global models against comparison to such individual events can be challenging because model errors in meteorological fields or emissions location can lead to large spatial displacement of the modeled plume relative to observations (e.g., Nam et al., 2010). The low horizontal and vertical resolution of global models, coupled with numerical diffusion can also lead to difficulties in reproducing plumes observed many thousands of kilometers downwind from source regions (e.g., Lin et al., 2010; Rastigejev et al., 2010; Real et al., 20101; TF-HTAP, 2010). Furthermore, generalizing from a few case studies conducted during a specific year or season can be difficult. 
In this study, we construct composite Asian and N. American aerosol outflow events based on dozens of individual cases for each season in order to examine the general features of these events. This approach provides more generality than individual long-range transport case studies, without losing useful information that is washed out by simple seasonal averaging. We apply this compositing methodology to the GEOS-Chem chemical transport model and to MODIS observations of aerosol optical depth (AOD) for the 20042010 period. In Sect. 2, we describe the model and satellite observations; we also validate the model prediction of AOD by comparison to MODIS. In Sect. 3, we present results from our compositing analysis for 244 Asian outflow events. We contrast outflow events from Asia to those from N. America in Sect. 4. Conclusions are presented in Sect. 5.

\section{Methods}

\subsection{MODIS AOD}

We use Level-3 (L3) daily MODIS AOD products at $550 \mathrm{~nm}$, derived by the standard dark-target retrieval algorithms over the ocean and land (Remer et al., 2005). When available, we also use AOD over land from the Deep Blue algorithm (Hsu et al., 2006), which is designed to retrieve aerosol properties over reflective surfaces. We use seven years (2004-2010) of the Collection 5.1 daily $1^{\circ} \times 1^{\circ}$ globally gridded datasets from the Aqua and Terra satellites. For comparison to model simulations, we regrid the L3 MODIS AOD observations to a $2^{\circ} \times 2.5^{\circ}$ resolution. Here and in the rest of the paper, MODIS AOD will always refer to total column AOD at $550 \mathrm{~nm}$. We select MODIS observations that satisfy the following criteria: cloud fraction smaller than $50 \%$; AOD value less than 3; at least 25 valid $10 \mathrm{~km} \times 10 \mathrm{~km}$ pixels within each $2^{\circ} \times 2.5^{\circ}$ grid box. This limits cloud contamination and produces statistically meaningful data (Zhang et al., 2005; Zhang and Reid, 2006). We use the pixel-weighting method (Levy et al., 2009) to calculate monthly, seasonal, and annual mean gridded AOD. Validation of the MODIS dark-target retrieval over the ocean (Remer et al., 2008) and land (Levy et al., 2010) demonstrates good agreement against AERONET observations. Remer et al. (2008) note that MODIS Terra retrievals over ocean have a 0.015 offset compared to Aqua, potentially due to changes in calibration.

In order to increase the spatial coverage of daily MODIS AOD, we combine observations from the Terra and Aqua satellites. We examine satellite retrievals in each grid box: if only one satellite has retrievals, then this AOD represents the final AOD; if both have retrievals, then the pixel-weighting averaging method (Levy et al., 2009) is applied and the mean value represents the final AOD.

The MODIS retrievals provide a measure of particle size with the fine mode fraction (FMF) parameter. In our analysis we will separate the fine AOD $($ AOD $\times$ FMF), which is the AOD attributed to submicron particles (diameter $<1 \mu \mathrm{m}$ ) often of anthropogenic origin, while the coarse AOD $(\mathrm{AOD} \times(1-\mathrm{FMF}))$ is attributed to supermicron particles (dust and sea salt) (Kaufman et al., 2005b).

\subsection{GEOS-Chem model}

We use the GEOS-Chem chemical transport model (v8-0204, http://acmg.seas.harvard.edu/geos/) to conduct a coupled aerosol-oxidant simulation for 2004-2010. GEOS-Chem is driven by assimilated meteorological observations from the Goddard Earth Observing System (GEOS) of the NASA Global Modeling and Assimilation Office. We use GEOS-5 meteorological fields, with a native horizontal resolution of $0.5^{\circ}$ latitude by $0.667^{\circ}$ longitude and 72 vertical levels, extending from the surface up to $0.01 \mathrm{hPa}$ (including 14 levels between the surface and $2 \mathrm{~km}$ altitude). For computational efficiency, we regrid these fields to a $2^{\circ} \times 2.5^{\circ}$ horizontal resolution. In addition, the top 37 levels $(70-0.01 \mathrm{hPa})$ are lumped into 11 levels leading to a reduced vertical grid with 47 layers.

The GEOS-Chem aerosol-oxidant simulation has been presented and evaluated in several previous studies (Park et al., 2003, 2004, 2005). The aerosol simulation includes sulfate (sulfate-ammonium-nitrate system) (Park et al., 2004), organic carbon (OC) and black carbon (BC) (Park et al., 2003), sea salt (Jaeglé et al., 2011), and soil dust (Fairlie et al., 2007). The simulation we are using here does not include an explicit formulation of secondary organic aerosol (SOA) formation from oxidation of biogenic volatile organic compounds such as isoprene and terpenes. All aerosol species are treated as externally mixed.

A detailed ozone- $\mathrm{NO}_{\mathrm{x}}$-hydrocarbon chemical mechanism is included in the tropospheric oxidant chemistry simulation (Bey et al., 2001b; Martin et al., 2003). The aerosol and oxidant chemistry are coupled through the formation of sulfate and nitrate, heterogeneous reactions, and aerosol effects on photolysis rates. All aerosol species are subject to dry deposition: sulfate, $\mathrm{OC}$, and $\mathrm{BC}$ follow a standard resistance-in-series scheme based on Wesely (1989) as implemented by Wang et al. (1998); dust and sea salt follow the size-dependent scheme of Zhang et al. (2001). Hydrophilic aerosols are subject to wet deposition as described in Liu et al. (2001), including rainout and washout from large scale precipitation, and scavenging in convective updrafts, allowing for return to the atmosphere after evaporation.

Interannually varying biomass burning emissions are taken from the GFEDv2 monthly inventory (van der Werf et al., 2006). The global anthropogenic emissions for GEOSChem are from the EDGAR 3.2 FT2000 global inventory. These emissions are scaled to the year 2006 using the approach described in van Donkelaar et al. (2008). Regional anthropogenic emissions over Asia are overwritten with the 2006 inventory of Zhang et al. (2009), and emissions over North America are overwritten with the 
2004-2010
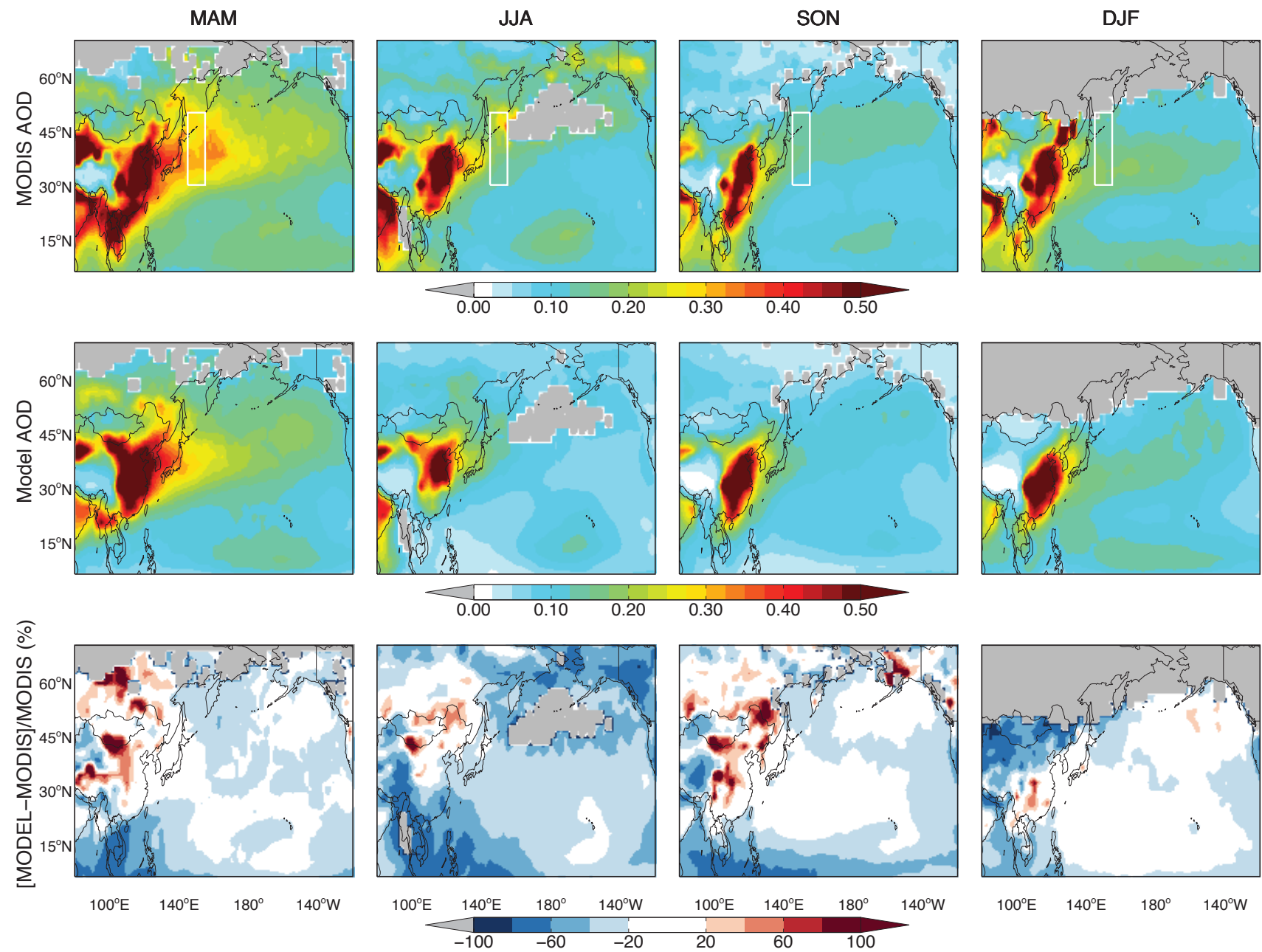

Fig. 1. Comparison between MODIS (top row) and GEOS-Chem (middle row) AOD over the North Pacific in different seasons over 20042010. From left to right: Spring (MAM), Summer (JJA), Fall (SON), and Winter (DJF). Panels in the bottom row show the percent difference between GEOS-Chem and MODIS AOD. The grey color represents missing data or cloudy conditions in the MODIS observations. The model is sampled only on the days when MODIS data is available. The white box in the top rows defines the Asian outflow region used in Fig. 2.

Environmental Protection Agency's National Emission Inventory for the year 2005. Over our 2004-2010 simulation period we keep anthropogenic emissions constant. We note that between 2006 and 2010, $\mathrm{SO}_{2}$ emissions from China have decreased by $9 \%$ (Lu et al., 2011), while US emissions have decreased by $50 \%$ (http://www.epa.gov/ttn/chief/ trends/index.html). Not taking into account the decline in $\mathrm{SO}_{2}$ anthropogenic emissions over the 2004-2010 period allows us to put equal weight on sulfate aerosol export events for all years and emphasizes the role of meteorology.

Optical properties are calculated in GEOS-Chem for each aerosol component as a function of local relative humidity (Martin et al., 2003). AOD at $550 \mathrm{~nm}$ is calculated from the mass concentration, extinction efficiency, effective ra- dius, and particle mass density with updated size distribution (Drury et al., 2010). For comparison to MODIS fine mode AOD, we combine GEOS-Chem sulfate-nitrateammonium, OC, BC and fine mode sea salt aerosols. For coarse mode AOD we add dust together with coarse mode sea salt aerosols. The daily model AOD is sampled only on the days and locations when cloud-free MODIS observations are available.

\subsection{Model evaluation}

Figure 1 shows the MODIS and GEOS-Chem seasonal mean AOD over the N. Pacific Ocean for 2004-2010. The model and observations display their largest AOD enhancements 

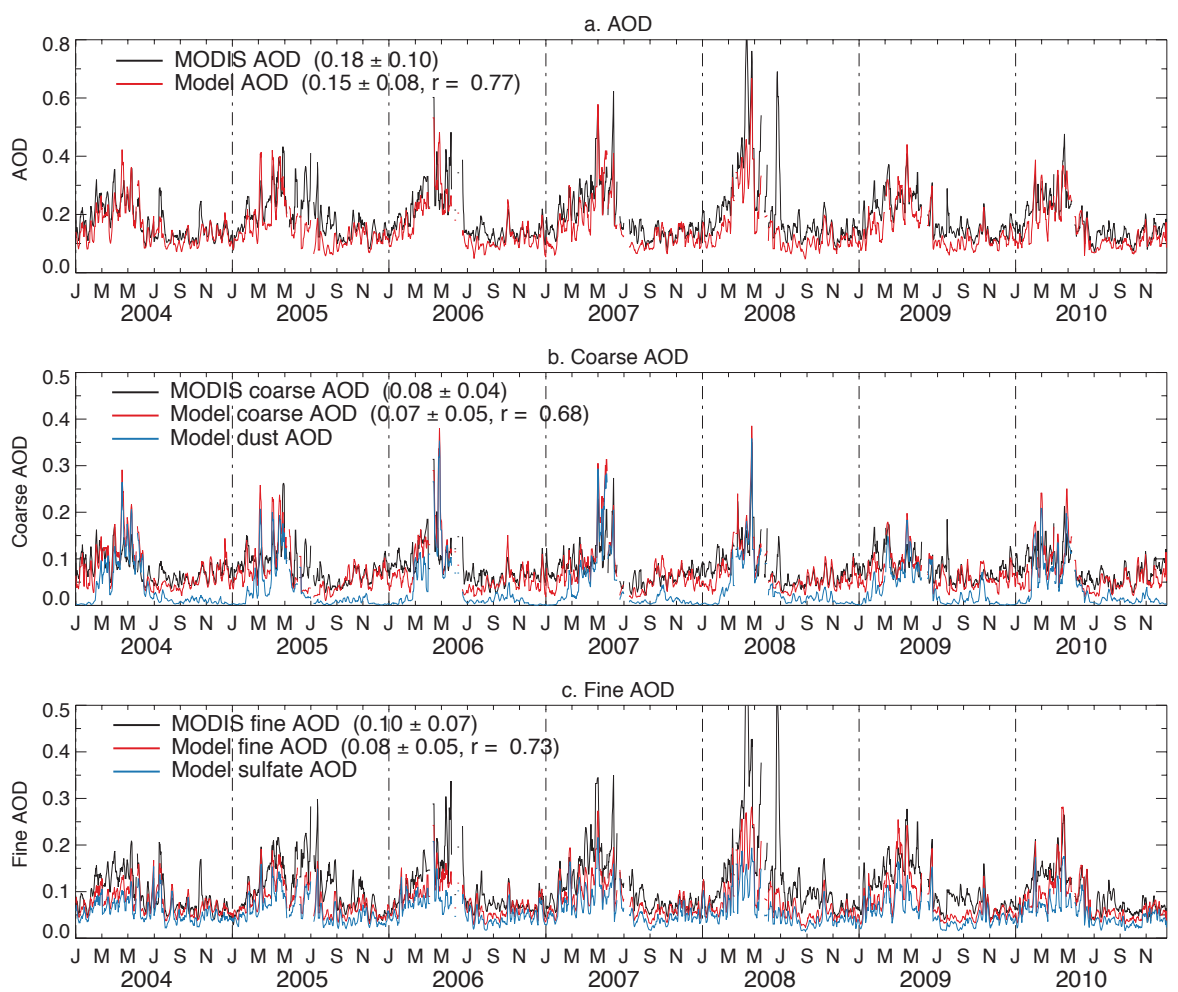

Fig. 2. Daily timeseries of AOD in the Asian outflow region $\left(145^{\circ}-155^{\circ} \mathrm{E}, 30^{\circ}-50^{\circ} \mathrm{N}\right.$, white box in Fig. 1) for 2004-2010: (a) total AOD, (b) coarse AOD, (c) fine AOD. MODIS AOD is shown in black and GEOS-Chem AOD in red. In addition, modeled dust AOD is shown in panel $b$ (blue line) and modeled sulfate in panel c (blue line). A 5-day running mean was applied to the daily AOD for both MODIS and GEOS-Chem.

during spring (March-May), as a result of frequent pollution export events combined with dust storms and, for some years, boreal biomass burning emissions. The AOD decreases from $0.2-0.4$ during spring to values $<0.2$ for other seasons. The increase in AOD over the central N. Pacific Ocean during winter (December-February) is associated with sea salt produced by strong winds in the storm track. Note that the lack of MODIS observations over the N. Pacific Ocean during JJA is due to persistent cloud cover in that region. Over the ocean, the model exhibits a negative bias ranging from 10 to $40 \%$ (Fig. 1, bottom panels). The agreement is particularly good during winter and spring (with a bias generally smaller than $-20 \%)$. The largest model underestimate occurs in summer, with a $20-40 \%$ negative bias over most of the N. Pacific. Potential reasons for this underestimate are examined below.

Figure 2 compares the 2004-2010 daily timeseries of observed and modeled AOD in the Asian outflow region over the NW Pacific ocean $\left(145^{\circ}-155^{\circ} \mathrm{E}, 30^{\circ}-50^{\circ} \mathrm{N}\right.$, as defined by the white box in Fig. 1). We only display days with at least $20 \%$ valid MODIS observations within the selected region. We then apply a 5-day running mean to both modeled and observed timeseries. The model total AOD shows a small negative systematic bias ( $-17 \%)$, but displays good temporal correlation $(r=0.77)$ with MODIS (Fig. 2a). The model reproduces the seasonal cycle, and captures most of the synoptic-scale transport events. On average, modeled coarse AOD is lower by $0.01(12 \%)$ compared to MODIS, while fine AOD is lower by $30 \%$ in the Asian outflow region (Fig. 2b,c). The model negative bias for fine AOD is largest during late spring and summer. Some of this underestimate might be due to model representation of boreal biomass burning. In our GEOS-Chem simulation, biomass burning emissions, like all surface emissions, are confined to the boundary layer, while in reality a significant fraction of plumes generated by fires might be injected in the free troposphere, enhancing their long-range transport (e.g., Leung et al., 2007; Turquety et al., 2007). The underestimate of AOD over biomass burning source regions of Siberia, Alaska, and Northern Canada during summer can be seen in Fig. 1. The fact that we do not include an explicit SOA mechanism in our GEOS-Chem simulation might also contribute to this underestimate. However, Lapina et al. (2011) used a GEOS-Chem simulation with land biogenic SOA formation and still noted a systematic GEOS-Chem underestimate of MODIS AOD by $20 \%$ over the remote oceans, which they attributed to a combination of satellite retrieval bias and a missing marine aerosol source. They found that inclusion of a marine organic matter source did not help reduce this bias. 

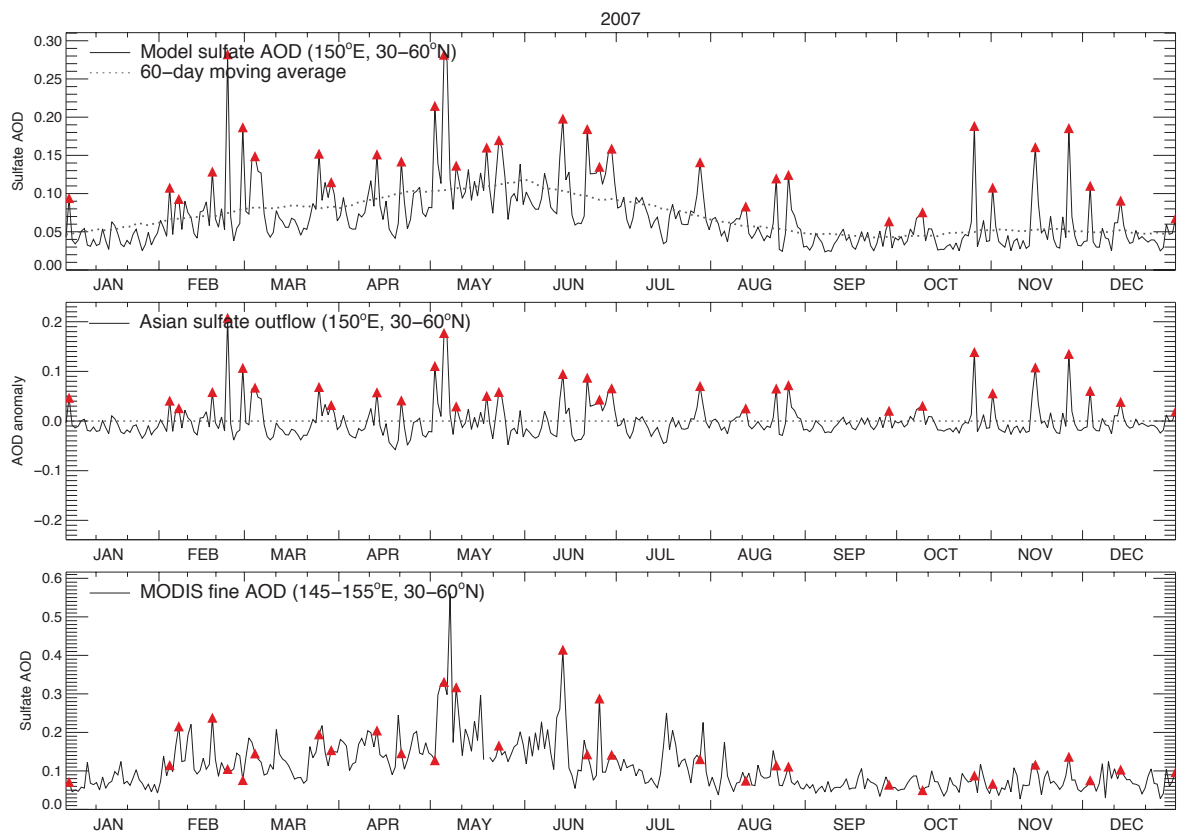

Fig. 3. Top: Daily GEOS-Chem sulfate AOD averaged in the Asian outflow region $\left(30-60^{\circ} \mathrm{N}, 150^{\circ}\right.$ E, black solid line) for the year 2005 . The dashed line indicates the 60-day running mean. Middle: Sulfate AOD anomalies "Asian outflow timeseries" (timeseries on top panel minus the 60-day running mean). Bottom: Daily MODIS fine AOD at $30-60^{\circ} \mathrm{N}, 145-155^{\circ} \mathrm{E}$ for 2007 . Red triangles indicate the 33 enhanced Asian export LRT' days identified using the GEOS-Chem "Asian outflow timeseries", as described in Sect. 3.1.

In addition several previous studies have validated GEOSChem against aircraft and ground-based aerosol observations in the E. Asian outflow and over the N. American west coast. For example, GEOS-Chem captured both the timing and distribution of Asian dust outbreaks during the TRACE-P and ACE-Asia aircraft experiments conducted in spring 2001 (Fairlie et al., 2007). The model also reproduced observed vertical profiles of dust aerosols in transpacific plumes during the INTEX-B aircraft campaign in April 2006 (Fairlie et al., 2010). While there was no significant bias in modeled Asian $\mathrm{SO}_{\mathrm{x}}$ (gas phase $\mathrm{SO}_{2}+$ sulfate aerosol) outflow during TRACE-P (Park et al., 2005), Heald et al. (2005) found that modeled sulfate aerosol concentrations were $50 \%$ too high during ACE-Asia. The sulfate overestimate could be due to model error in the $\mathrm{SO}_{2}$ oxidation rate. More recently, van Donkelaar et al. (2008) found that GEOS-Chem also captures the mean INTEX-B aircraft profiles of $\mathrm{SO}_{\mathrm{x}}$ (gas phase $\mathrm{SO}_{2}+$ sulfate aerosol) and sulfate over the NE Pacific Ocean with a positive bias ranging from 2.5 to $59 \%$. The model reproduced the observed profiles of BC during TRACE-P and ACE-Asia (Park et al., 2005; Heald et al., 2005), but underestimated OC profiles by a factor of 10-100 in the free troposphere. Over the N. Eastern Pacific Ocean during INTEXB, GEOS-Chem captured the observed OC profile (Dunlea et al., 2009). Heald et al. (2011) show that including an additional anthropogenic source of SOA leads to improved agreement to OC mass concentration observations near continents.

\section{Composites of aerosol export events from East Asia}

In this section we identify hundreds of outflow events based on the GEOS-Chem sulfate AOD timeseries for 2004-2010. We then composite these events by season to identify general patterns in the horizontal location of AOD enhancements, the vertical distribution of aerosols, and common meteorological features associated with export.

\subsection{Identification of export events}

Most of the pollution export from East Asia to the NW Pacific Ocean occurs over the $30^{\circ}-60^{\circ} \mathrm{N}$ latitude range (Liang et al., 2005). We thus analyze daily variations in GEOSChem sulfate AOD averaged over this latitude band at $150^{\circ} \mathrm{E}$ longitude for 2004-2010. We choose sulfate aerosols as a proxy for pollution aerosols, as they are one of the dominant components of anthropogenic aerosols found in trans-Pacific plumes (e.g., Brock et al., 2004; Dunlea et al., 2009). The model sulfate AOD timeseries at $150^{\circ} \mathrm{E}$ is shown in Fig. 3 (top panel) for the year 2007. Timeseries for other years are similar. Daily sulfate AOD is highly episodic, with the strongest outflow events occurring during spring, but with significant events also taking place during other seasons as noted in previous studies (Yienger et al., 2000; Jaeglé et al., 2003; Liang et al., 2004). We apply a 60-day high-pass filter to remove the seasonal cycle. We will refer to the resulting sulfate AOD anomalies timeseries as the "Asian outflow 
timeseries" (Fig. 3, middle panel). By plotting the probability distribution function of the Asian outflow timeseries, we find that it is log-normally distributed. We define enhanced aerosol export events during spring as the top $20 \%$ days in the frequency distribution of the Asian outflow timeseries for 2004-2010. For other seasons, we use the top $15 \%$ as a threshold, since during these seasons the frequency distributions are narrower, indicating fewer enhanced transport episodes. We will refer to these enhanced outflow days as "LRT ${ }^{+}$events". In cases where outflow events occur over a period of 2-3 days (which occurs for $40 \%$ of the events), we only keep the day with the highest AOD enhancement to avoid multiple counting. The red triangles in Fig. 3 correspond to the $33 \mathrm{LRT}^{+}$days identified in 2007 (10 in spring, 8 in summer, 6 in fall and 9 in winter). There appears to be reasonable correspondence between $\mathrm{LRT}^{+}$days identified with the model and elevated fine mode AOD values measured by MODIS (Fig. 3, bottom panel). Out of the 33 events identified in the model, 22 correspond to peaks in MODIS fine AOD with another 5 events occurring within 1 day of a peak in MODIS.

For the 2004-2010 time period, we have identified 244 LRT $^{+}$days: 81 in spring, 47 in summer, 56 in fall and 60 in winter. This corresponds to a mean frequency of one event every 8 days during spring, decreasing to one event every 14 days during summer. Note that pollution export out of East Asia is often accompanied by export of dust aerosols (Uematsu et al., 1983; Jaffe et al., 1999; Uno et al., 2001; Takemura et al., 2002; Huebert et al., 2003). Indeed, as dust storms from the Gobi Desert and Taklimakan Desert move to East China, the strong winds often sweep anthropogenic aerosols out of the polluted regions to the N. Pacific Ocean. We find that in 54 of the $81 \mathrm{LRT}^{+}$spring events, dust was also exported in significant amounts.

\subsection{Composites of export events}

For each season, we generate composite maps averaging all $\mathrm{LRT}^{+}$days over the NW Pacific Ocean. Fig. 4 shows the composites of GEOS-Chem AOD anomalies (top row) and MODIS AOD anomalies (middle row). We define anomalies as the difference between the mean AOD on $\mathrm{LRT}^{+}$ days minus the seasonal average. For example, the spring $\mathrm{LRT}^{+}$composite is calculated by taking the mean model AOD for the $81 \mathrm{LRT}^{+}$days identified in MAM and subtracting the spring mean AOD for 2004-2010. During LRT ${ }^{+}$ events, GEOS-Chem predicts large AOD enhancements extending from southern Japan to the Kamchatka Peninsula. At $150^{\circ} \mathrm{E}$, AOD anomalies reach $\sim 0.1-0.15$, corresponding to a 50-100\% enhancement relative to seasonal mean values (Fig. 4a). The pattern is consistent from season to season. MODIS AOD composites on those same $\mathrm{LRT}^{+}$days display a similar pattern, although not matching the exact shape of the modeled enhancement, possibly as a result of the patchy sampling of MODIS (Fig. 4b).
A composite of vertical profiles of model aerosol extinction coefficients at $150^{\circ} \mathrm{E}$ (Fig. 4c) shows that transport of sulfate occurs mostly below $4 \mathrm{~km}$ altitude, with maximum enhancements at $1-3 \mathrm{~km}$. The $\mathrm{LRT}^{+}$sulfate extinction coefficients are enhanced by a factor of two relative to seasonal mean values. During spring, substantial amounts of dust also get transported on $\mathrm{LRT}^{+}$days, but at higher altitudes $(\sim 2-$ $8 \mathrm{~km}$ ) as a result of the elevated topography of Asian deserts. Studies based on the CALIOP space-borne lidar found Asian dust layers transported at altitudes ranging from $4 \mathrm{~km}$ to $9 \mathrm{~km}$ (Huang et al., 2008; Uno et al., 2008; Eguchi et al., 2009), consistent with model results (e.g., Heald et al., 2006a; Nam et al., 2009). In GEOS-Chem, dust aerosols account for $30 \%$ of the total AOD enhancement during spring $\mathrm{LRT}^{+}$days.

Figure 5 shows composite meteorological fields two days before $\mathrm{LRT}^{+}$days. This 2-day lag corresponds to the average transport time from East China to $150^{\circ} \mathrm{E}$ (Liang et al., 2005). Sea level pressure (SLP) anomaly composites (filled contours in Fig. 5, top panels) display an east-west dipole structure in spring, fall and winter, with a negative SLP anomaly of 3$8 \mathrm{hPa}$ over NE China and a positive anomaly of $2-5 \mathrm{hPa}$ over Japan. During summer, the negative SLP anomaly is much weaker. The negative SLP anomaly in spring, fall and winter is indicative of surface low pressure systems over NE China, inducing strong convergent flow (southwesterly and northwesterly winds) over eastern China as shown by the $850 \mathrm{hPa}$ wind speed anomalies (Fig. 5, bottom panels). This anomaly corresponds to an $850 \mathrm{hPa}$ trough, upward motion, and a precipitation band (not shown), all implying the influence of a midlatitude cyclone system. Cyclones over NE China are related to lee cyclogenesis, originating over three main regions: the Altai-Sayan mountain ranges, Lake Baikal (south of the Stanovoi mountain range), and east of the Great Xinganling Mountains in NE China (Chen et al., 1991). These cyclones occur year-round, with a maximum frequency in spring and a minimum in winter.

The positive SLP anomaly and reduced wind speeds over the NW Pacific Ocean near Japan are consistent with the presence of stagnant conditions 2 days before $\mathrm{LRT}^{+}$events conducive to pollution accumulation over NE China. These conditions are favorable for build-up and then export of anthropogenic aerosol from this highly polluted region to the N. Pacific Ocean. The weak summer SLP signature indicates that cyclones are not the main meteorological mechanism leading to export in that season, with convection likely playing a more dominant role. During winter, the widespread negative SLP anomaly over Eastern China represents a weakening of the Siberian High, accounting for less stable boundary layer conditions over these regions. This induces strong northwesterly winds at lower altitudes, which contribute to the enhanced sulfate outflow at these levels (from the surface to $3 \mathrm{~km}$, see Fig. 4). By examining individual outflow events, we find that some occur behind cold fronts, while others are ahead of cold fronts. 
a) Model AOD LRT ${ }^{+}$composites
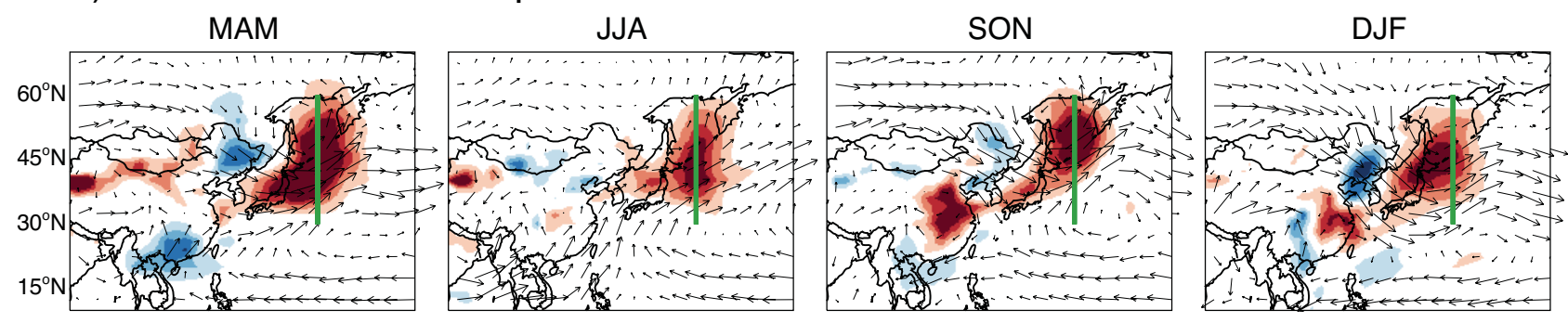

b) MODIS AOD LRT' ${ }^{+}$composites
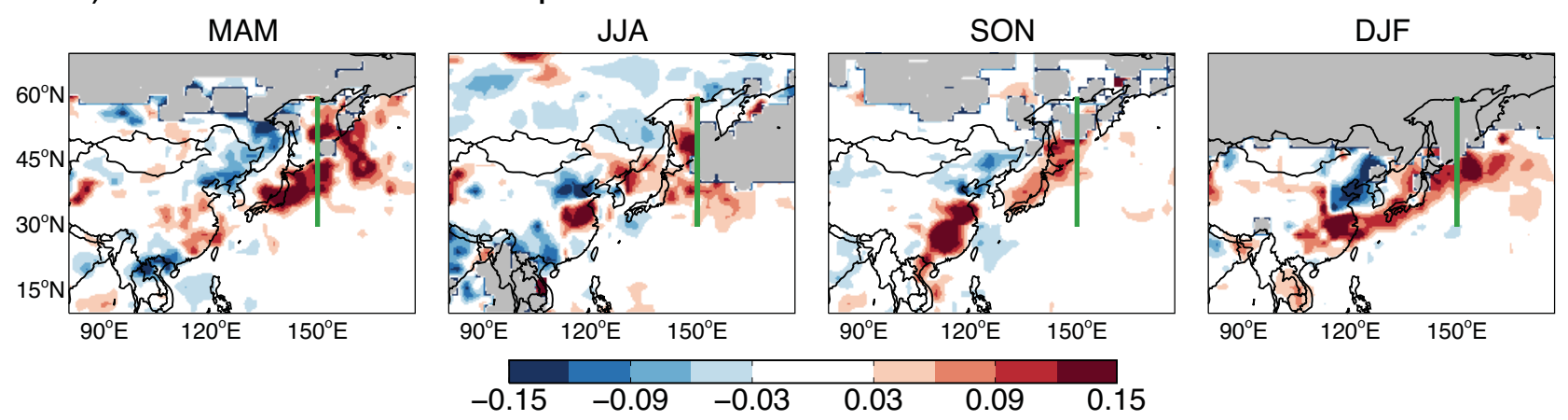

c) Aerosol extinction profile
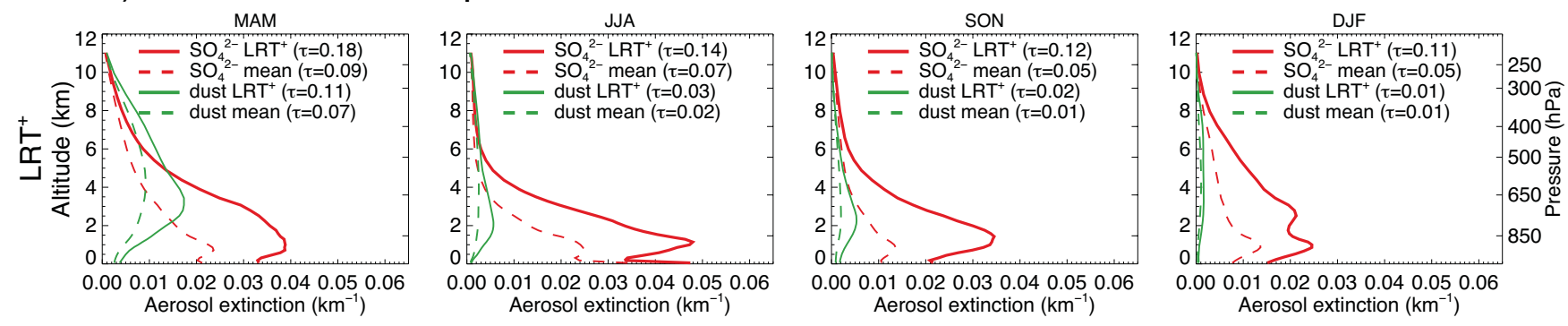

Fig. 4. Seasonal composites of AOD anomalies (defined as the difference between the AOD on LRT ${ }^{+}$days and the seasonal mean AOD) and extinction profiles over the NW Pacific Ocean on LRT ${ }^{+}$days. From left to right: spring (MAM), summer (JJA), fall (SON), and winter (DJF). (a) GEOS-Chem AOD anomalies (filled contours) with $850 \mathrm{~h} \mathrm{~Pa}$ wind fields (arrows). The green line $\left(150^{\circ} \mathrm{E}, 30^{\circ}-60^{\circ} \mathrm{N}\right)$ indicates the wall defining our Asian outflow timeseries. (b) MODIS AOD anomalies. The grey color represents missing data or cloudy conditions in the MODIS observations. (c) GEOS-Chem extinction profiles of sulfate (red) and dust (green) at $150^{\circ} \mathrm{E}, 30^{\circ}-60^{\circ} \mathrm{N}$. The dashed lines indicate the seasonal average, while the solid lines correspond to mean profiles on $\mathrm{LRT}^{+}$days. The mean values for the AOD are indicated in the figure caption.

Liang et al. (2005) correlated daily modeled Asian anthropogenic CO column in the outflow region with the local SLP anomaly 2 days earlier for the 1992-2002 period. They found a strong negative correlation centered over NE China at $45^{\circ} \mathrm{N}$, indicating that midlatitude cyclones were the dominant synoptic scale influence on export of Asian CO across all seasons. The SLP anomaly pattern displayed in Fig. 5 is very similar to the pattern found in Liang et al. (2005), and confirms the strong role of midlatitude cyclones in the export of aerosols from E. Asia for all seasons, with the exception of summer.

\subsection{Evolution of export events over the N. Pacific Ocean during spring}

Once a pollution plume is exported to the NW Pacific Ocean, its evolution is controlled by the meteorological conditions downstream. Liang et al. (2005) and Reidmiller et al. (2010) found that enhanced transpacific transport is characterized by the combined effects of a strong Pacific High and a strong low over Alaska. Fig. 6 shows the evolution of GEOSChem spring AOD anomaly composites starting 2 days before $\mathrm{LRT}^{+}$days and continuing for the 6 days following these enhanced export days. Instead of the absolute AOD 
a)

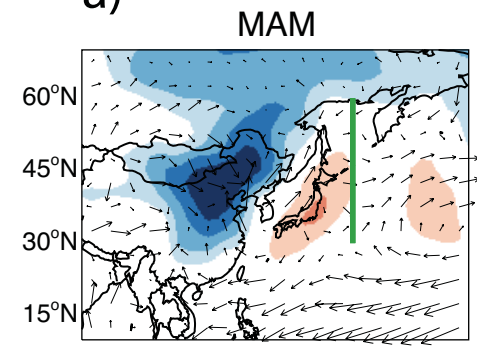

b)

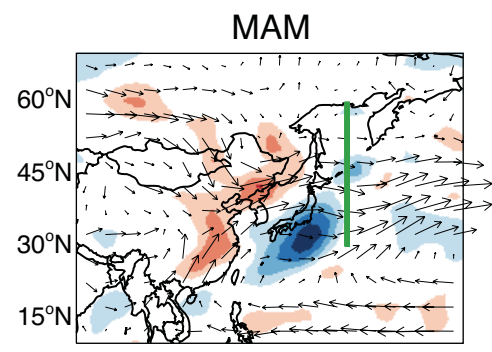

JJA

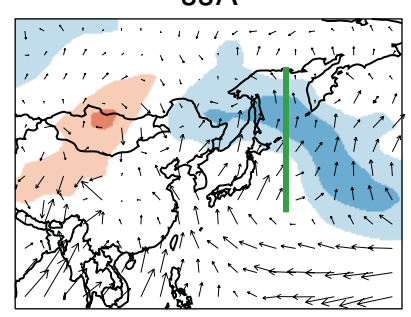

SON
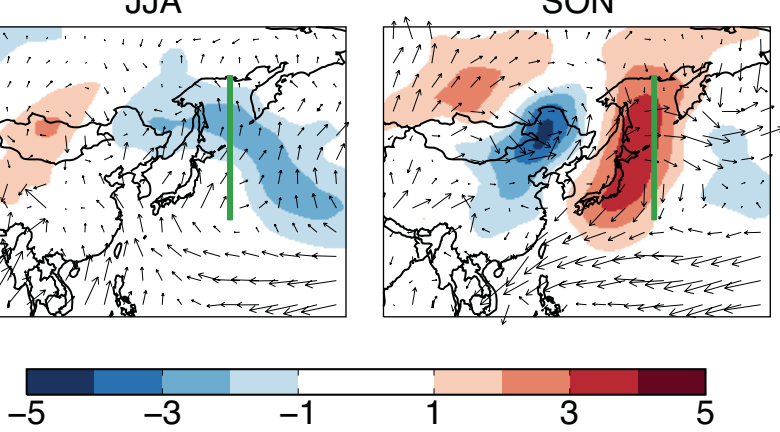

JJA

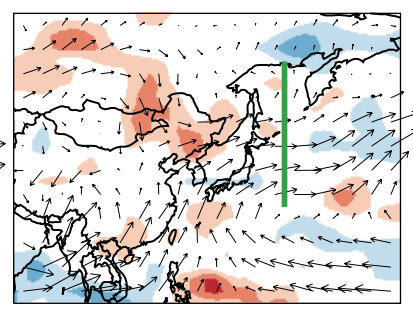

SON

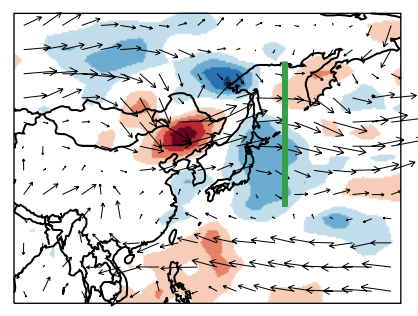

1.5 2.5

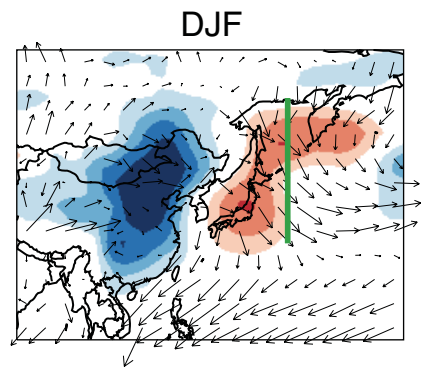

$\mathrm{hPa}$

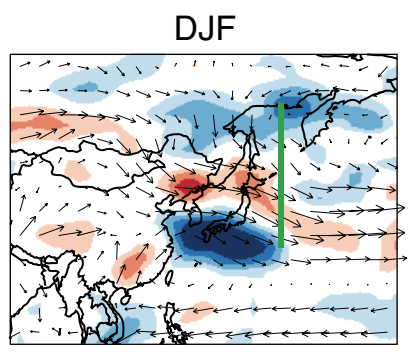

$\mathrm{m} / \mathrm{s}$

Fig. 5. Seasonal composites of meteorological fields anomalies 2 days before E. Asian $\mathrm{LRT}^{+}$events relative to the seasonal means for $2004-$ 2010. Top: sea level pressure anomalies (filled contours) and surface wind fields (arrows indicate direction and speed). Bottom: $850 \mathrm{hPa}$ wind speed anomalies (filled contours) and wind fields (arrows).

anomalies relative to mean seasonal conditions (as used in Fig. 4), we show the anomalies expressed as a percentage relative to mean seasonal conditions. This emphasizes the influence of the composite Asian plume as it travels over cleaner conditions in the central and eastern Pacific Ocean. The resulting composite evolution of export events displays some coherence for a period of 6-9 days. This illustrates that despite the variability of the 81 individual export events (with different composition, latitudes, altitudes, and speeds), the composite can capture some common patterns. We further test the general nature of the patterns shown in Fig. 6 by eliminated the top $3 \%$ of transport events. The resulting composites remain nearly unchanged (not shown).

At $\mathrm{LRT}^{+}-2$ days, there is a strong AOD enhancement over NE China. This enhancement is transported to our wall at $150^{\circ} \mathrm{E}$ in 2 days, and reaches the central Pacific 2 days later $\left(\mathrm{LRT}^{+}+2\right.$ days). The composite plume splits into two branches, with the lower latitude branch $\left(<45^{\circ} \mathrm{N}\right)$ being transported eastward, and the high latitude branch $\left(>45^{\circ} \mathrm{N}\right)$ being transported poleward to the Arctic. By examining individual transport events, we find that the poleward transport events reach the Arctic in 3-4 days and are favored by the presence of a blocking high-pressure system in the N. Pacific Ocean, similar to the results of Di Pierro et al. (2011) and Matsui et al. (2011). Over the next 3 days, the lower latitude aerosol plume is transported across the N. Pacific
Ocean, reaching the west coast of N. America 4-6 days after the $\mathrm{LRT}^{+}$export events, thus taking a mean 6-8 day transport time from East China to the N. American west coast. This rapid plume transport time is consistent with previous studies (e.g., Yienger et al., 2000; Holzer et al., 2003, 2005; TF-HTAP, 2010 and references therein). The magnitude of the AOD enhancement over the N. American west coast is $\sim 10-20 \%$ above the seasonal mean column AOD values, extending from Alaska to California. Some of the composite plume can also be trapped in the Pacific High and recirculates in the subtropics, as suggested by the AOD enhancements on $\mathrm{LRT}^{+}+5-6$ days south of $30^{\circ} \mathrm{N}$ (Fig. 6). The perturbation lasts for several days, implying a long lifetime of aerosols in the dry environment of the descending air masses in the Pacific High.

The composite evolution of MODIS AOD anomalies (Fig. 6, bottom panels) shows similar, though very noisy, spatial distributions as the model between $\mathrm{LRT}^{+}-2$ days and $\mathrm{LRT}^{+}+0$ day. Beyond $\mathrm{LRT}^{+}+0$ day, the MODIS AOD anomalies become very noisy over the N. Pacific Ocean and no coherent plume emerges from the resulting composites. This is due to frequent cloud cover and thus patchy sampling of individual plumes by MODIS over the Pacific Ocean.

The corresponding composite evolution of SLP fields (not shown) displays a strong low pressure anomaly over Mongolia and southern Siberia, the Altai-Sayan lee cyclogenesis 
a) Evolution of composite AOD anomalies: GEOS-Chem
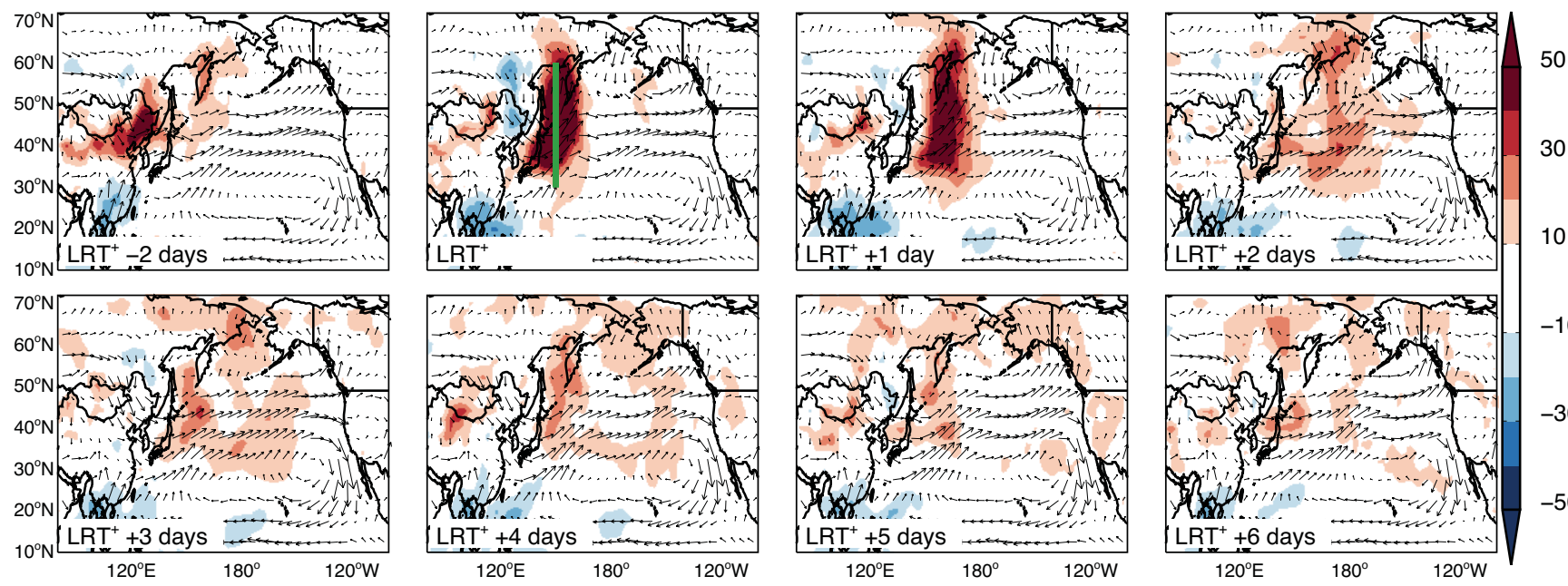

b) Evolution of composite AOD anomalies: MODIS
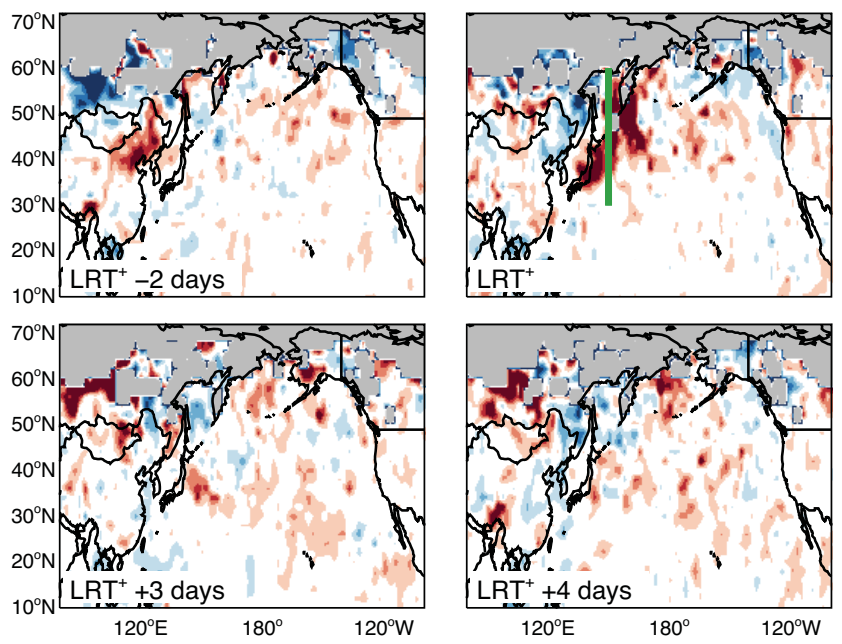
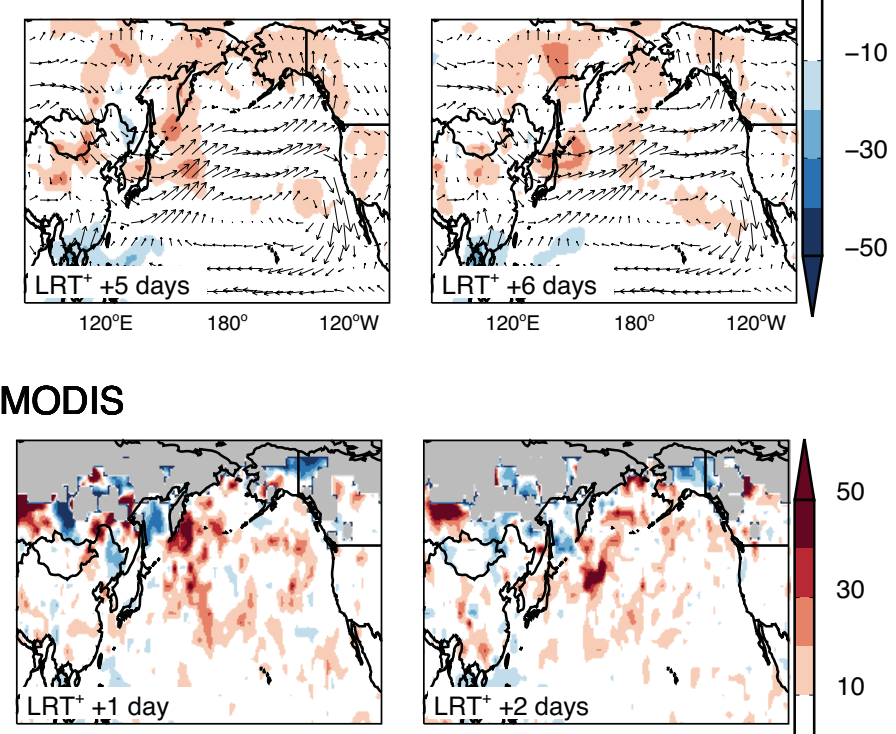

50 0

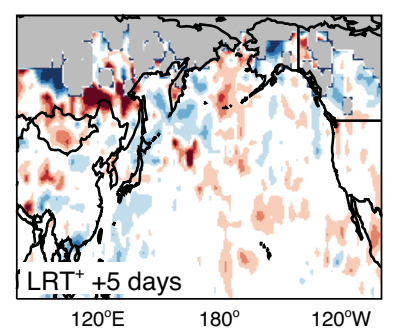

Fig. 6. Springtime evolution of AOD anomalies from 2 days prior to $\mathrm{LRT}^{+}$days to 6 days after $\mathrm{LRT}^{+}$days over the N. Pacific. The AOD anomalies are expressed in percent relative to seasonal mean AOD values. (a) GEOS-Chem AOD anomalies. Arrow indicated composites of $850 \mathrm{hPa}$ wind fields. (b) MODIS AOD anomalies.

region, on $\mathrm{LRT}^{+}$minus 3-4 days. This low pressure system is over NE China on days $\mathrm{LRT}^{+}$minus 2 and 1 day. Strong low-level northwesterly and southwesterly winds converge over the East coast of China, coincident with the rising motion ahead of midlatitude cyclones. As the cyclone moves towards the NE Pacific Ocean, the aerosol plume is transported offshore by the strong upper level winds ahead of the cyclone.

\section{N. American aerosol export compared to Asian export}

We now contrast aerosol export from E. Asia to export from N. America. Both regions are on the eastern parts of midlat- itude Northern Hemisphere continents and are heavily populated, with significant industrial activity. Both regions are located at the start of the storm tracks (Stohl et al., 2001; Eckhardt et al., 2004), so that export of pollution is dominated by the same meteorological mechanisms: midlatitude cyclones and seasonal convection. There are some major differences in terms of emissions of aerosols and their precursors. Anthropogenic emissions of $\mathrm{SO}_{2}$ are significantly higher over East Asia compared to N. America. In their 2006 anthropogenic emissions inventory, Zhang et al. (2009) estimate $31 \mathrm{Tg} \mathrm{SO} \mathrm{S}_{2}$ from China and $0.9 \mathrm{Tg}$ from Japan. For the year 2006, the Environmental Protection Agency (http:// www.epa.gov/ttn/chief/trends/index.html) reports $12 \mathrm{Tg} \mathrm{SO}_{2}$ 
from the US, and Environment Canada's National Pollutant Release Inventory (http://www.ec.gc.ca/inrp-npri/) reports $2 \mathrm{Tg}$ from Canada. Vegetation is abundant in the Eastern US, which leads to significant biogenic volatile organic compound (VOC) emissions during summer (e.g. Guenther et al., 1995; Millet et al., 2008; Warneke et al., 2010). In contrast, E. Asia with its more arid conditions has weaker biogenic VOC emissions (e.g., Guenther et al., 1995; Fu et al., 2008), but considerable dust emissions, especially during spring (e.g., Prospero et al., 2002; Shao and Dong, 2006).

Figure 7 compares the 2004-2010 monthly mean MODIS AOD in the outflow regions of $\mathrm{N}$. American $\left(65^{\circ}-55^{\circ} \mathrm{W}\right.$, $\left.30^{\circ}-50^{\circ} \mathrm{N}\right)$ and $\mathrm{N}$. America $\left(145^{\circ}-155^{\circ} \mathrm{E}, 30^{\circ}-50^{\circ} \mathrm{N}\right)$. On an annual mean basis, the observed AOD in the E. Asian outflow is $40 \%$ higher than in the N. American outflow. The enhancement in the Asian outflow relative to the N. American outflow is particularly strong during spring, reaching 70-100 \% during March-May. This is the result of both enhanced dust export and higher anthropogenic emissions of aerosol precursors over E. Asia. Annual mean fine AOD in the Asian outflow is $60 \%$ higher relative to the N. American outflow (Fig. 7c). Compared to N. America, coarse AOD is 40-70\% higher over E. Asia during February-May, when dust dominates (Fig. 7b). In other months, when sea salt dominates, coarse AOD is similar for both regions with a mean AOD of 0.07 observed by MODIS and captured by GEOS-Chem.

While MODIS AOD in the E. Asian outflow region has a pronounced spring maximum, the N. American outflow has a weaker seasonal variation, with a broad spring-summer enhancement. This is potentially due to a smaller seasonal contrast in meteorological conditions and cyclone activity over N. America. Indeed, when we compare the two source regions, we find a much larger seasonal range in temperature over E. Asia (max-min in monthly values: $31^{\circ} \mathrm{C}$ ) than over eastern N. America $\left(22^{\circ} \mathrm{C}\right)$. The same applies for wind speed (E. Asia: $2.4 \mathrm{~m} \mathrm{~s}^{-1}$; eastern N. America: $1 \mathrm{~m} \mathrm{~s}^{-1}$ ), relative humidity (E. Asia: 19\%; NE America: 4\%), and precipitation (E. Asia: $3.5 \mathrm{~mm} \mathrm{day}^{-1}$; eastern N. America: $1.9 \mathrm{~mm} \mathrm{day}^{-1}$ ).

The weaker seasonal contrast in the N. American outflow could also be the result of enhanced SOA production and export during summer from the Eastern US. Indeed the GEOS-Chem model AOD predicts a small spring maximum in AOD in the N. American outflow region, however it tends to underestimate summertime fine AOD. As noted in Sect. 2, SOA formation from biogenic VOCs is not included in our GEOS-Chem simulation. This source accounts for $30 \%$ of the OC source over the eastern US during summer (Heald et al., 2006b). The study of Lapina et al. (2011) did include this additional OC source as well as an estimate of a marine organic matter source. However, neither OC source could explain the gap between GEOS-Chem and MODIS AOD over marine regions.
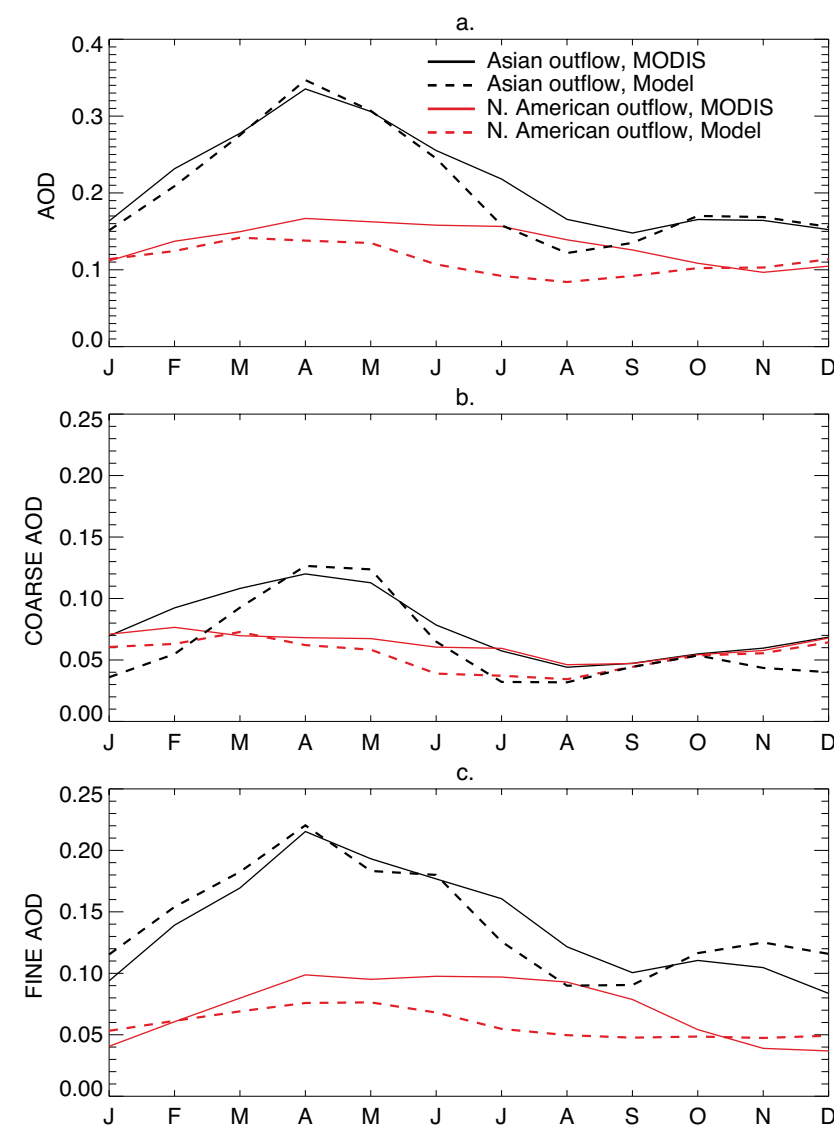

Fig. 7. Seasonal evolution of MODIS (solid lines) and GEOS-Chem (dotted lines) $550 \mathrm{~nm}$ AOD in the E. Asian and N. American outflow regions in the NW Pacific Ocean $\left(145^{\circ}-155^{\circ} \mathrm{E}, 30^{\circ}-50^{\circ} \mathrm{N}\right.$, black) and NW Atlantic Ocean $\left(65^{\circ}-55^{\circ} \mathrm{W}, 30^{\circ}-50^{\circ} \mathrm{N}\right)$ for $2004-2010$. Individual panels show the total AOD (a), coarse mode AOD (b) and fine mode AOD (c).

\subsection{Composites of export events from N. America}

Using the methodology described in Sect. 3.1, we define a "N. American outflow timeseries" based on daily GEOS-Chem sulfate AOD timeseries over the Western North Atlantic Ocean $\left(65^{\circ}-55^{\circ} \mathrm{W}, 30^{\circ}-50^{\circ} \mathrm{N}\right)$. We identify 251 $\mathrm{LRT}^{+}$events for 2004-2010 (72 events in spring, 60 in summer, 61 in fall and 58 in winter). During $\mathrm{LRT}^{+}$events, the composites for modeled and MODIS fine mode AOD anomalies display strong positive anomalies around $60^{\circ} \mathrm{W}$, with AOD enhancements of $0.04-0.08$, corresponding to a 50 $100 \%$ increase relative to mean seasonal AOD (Fig. 8a,b). The AOD enhancement pattern is similar for all seasons. We note that while we use the same procedure to identify $\mathrm{N}$. American export events as in E. Asia, the number of $\mathrm{LRT}^{+}$events from N. America (251) is slightly higher than from E. Asia (244). This is because E. Asian outflow events can last longer than N. American events. And thus more multi-day events are eliminated to avoid double counting. 
a) Model AOD LRT ${ }^{+}$composites
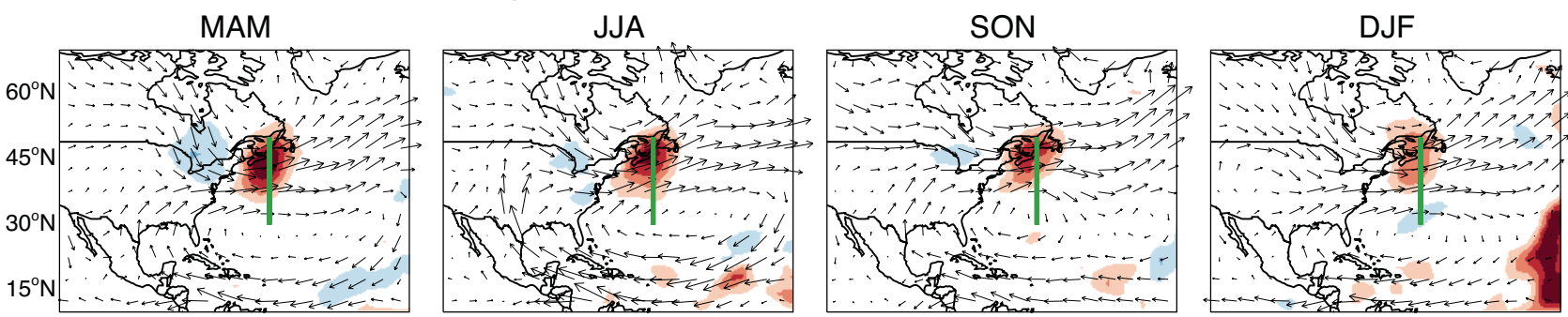

\section{b) MODIS AOD LRT ${ }^{+}$composites}
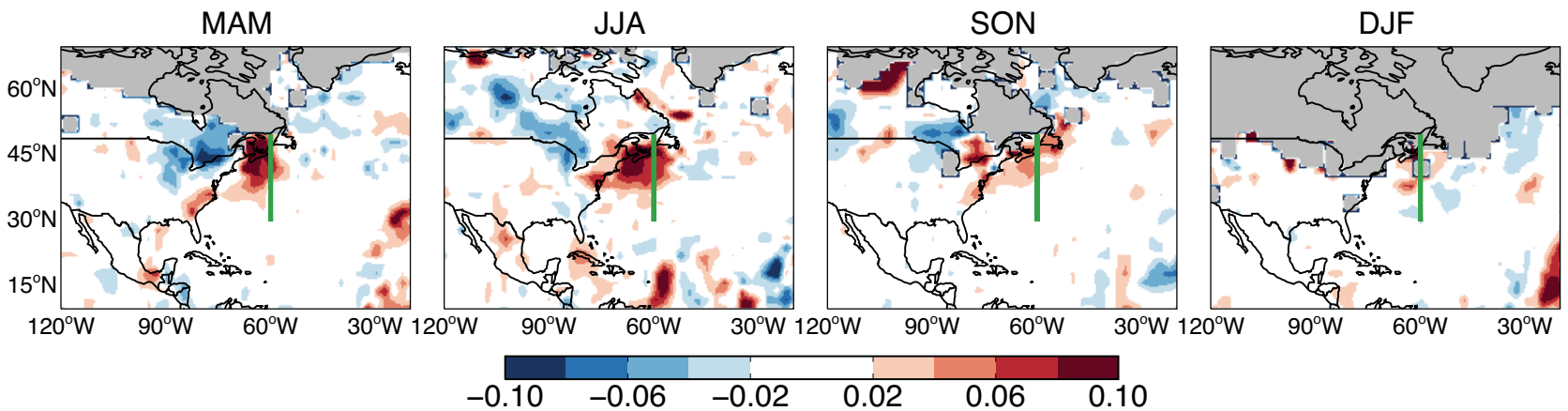

$-0.1$

\section{c) Aerosol extinction profile}
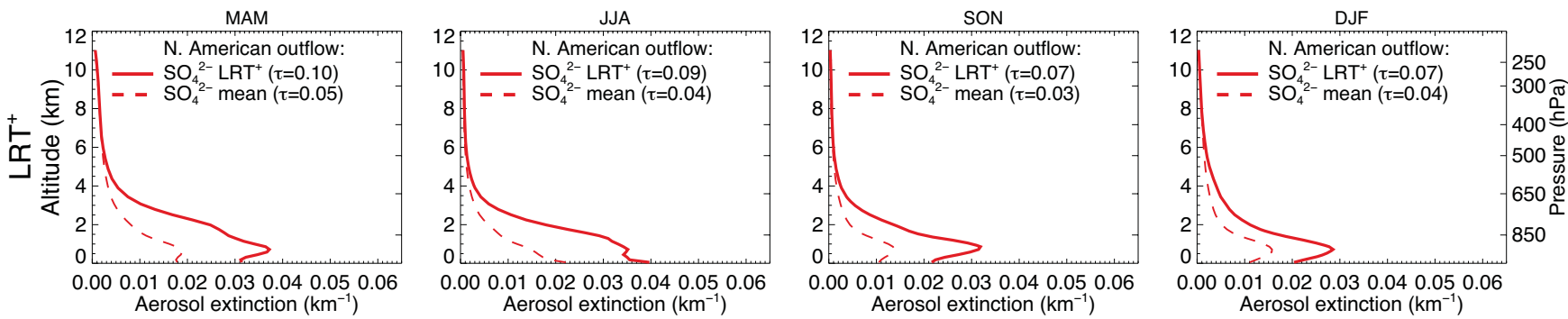

Fig. 8. Seasonal composites of AOD anomalies and extinction profiles over the NW Atlantic on LRT ${ }^{+}$days. (a) GEOS-Chem AOD anomalies (filled contours) with $850 \mathrm{hPa}$ wind fields (arrows). (b) MODIS AOD anomalies. (c) GEOS-Chem extinction profiles of sulfate aerosols at $60^{\circ} \mathrm{W}, 30^{\circ}-50^{\circ} \mathrm{N}$ (location indicated by green line in panels (a) and (b). The dashed lines indicate the seasonal average, while the solid lines correspond to mean profiles on $\mathrm{LRT}^{+}$days.

The composite modeled vertical profiles of sulfate aerosol extinction coefficients on $\mathrm{LRT}^{+}$days (Fig. 8c) shows a maximum at $1 \mathrm{~km}$, and then decrease rapidly with altitude. During $\mathrm{LRT}^{+}$events, the sulfate AOD is a factor of two higher relative to mean seasonal conditions, a similar relative enhancement to what we had found downwind of E. Asia. Spring and summer display the largest AOD enhancements, suggesting stronger export during these seasons.

The composite SLP anomalies 2 days prior to $\mathrm{LRT}^{+}$ events display a dipole structure, with a $3-5 \mathrm{hPa}$ negative anomaly over continental N. America, and a positive anomaly over the eastern part of the continent, extending over the NW Atlantic Ocean. This structure is similar to that which facilitates export from E. Asia, but the negative anomalies are centered farther inland. The negative SLP anomalies are associated with surface low pressure systems over the central US. This dipole structure induces strong southwesterly winds at lower altitudes extending from Texas to the Great Lakes region (Fig. 9, bottom panels). The southwesterly winds then converge with northwesterly winds near the US-Canada border leading to favorable conditions for outflow of anthropogenic aerosols from these relatively polluted regions out to the NW Atlantic Ocean.

Composites of SLP anomalies on $\mathrm{LRT}^{+}$days (without any lag) display a negative SLP anomaly over the Gulf of Saint Lawrence and Quebec. This represents the moving low pressure center ventilating the N. American boundary layer and exporting aerosols to the NE Atlantic Ocean. The role of migratory midlatitude cyclones in controlling the export of pollution from N. America is consistent with previous studies (e.g., Merrill and Moody, 1996; Stohl, 2001; Auvray and Bey, 2005; Fang et al., 2009). In particular, Fang et al. (2009) 

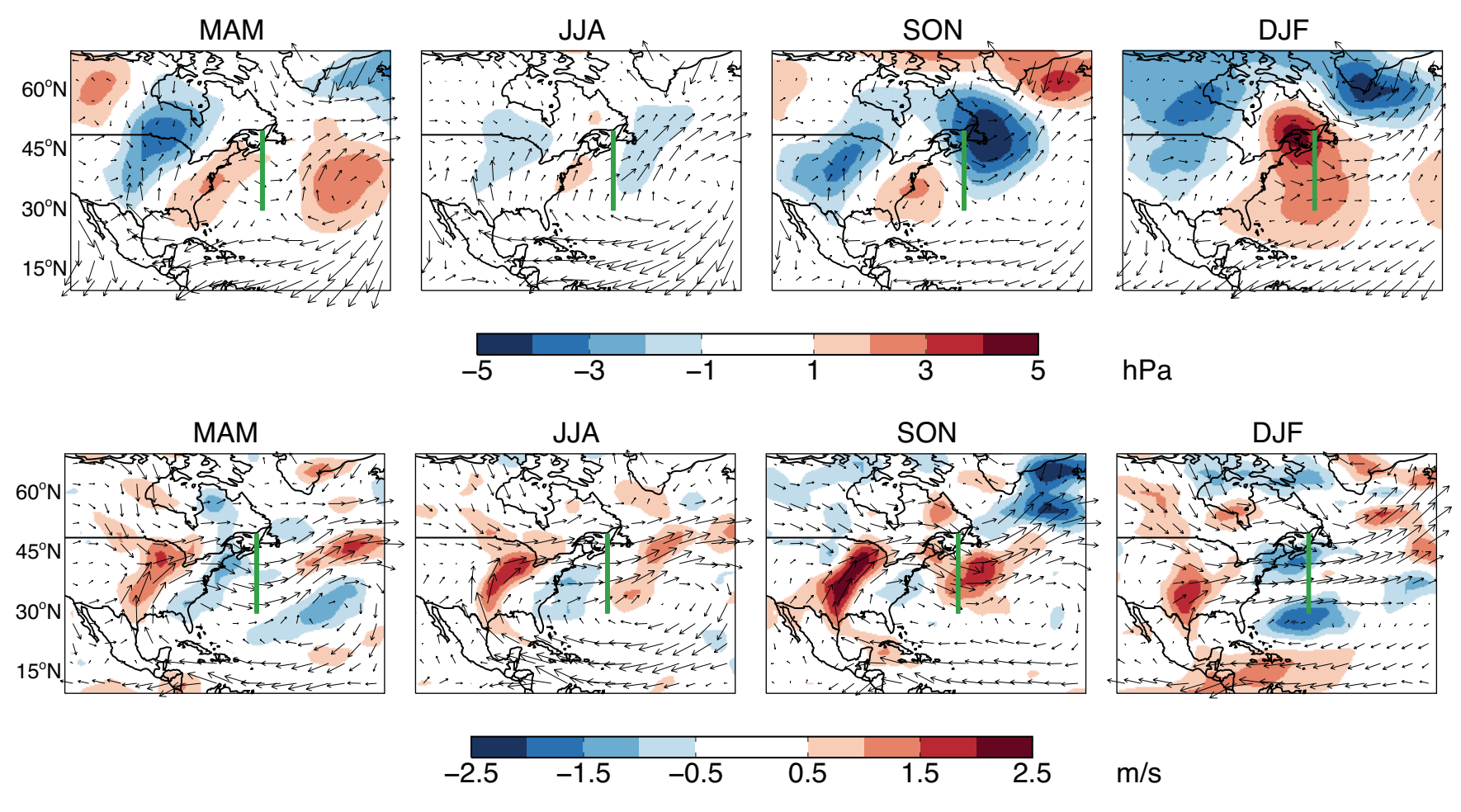

$\mathrm{m} / \mathrm{s}$

Fig. 9. Seasonal composites of meteorological field anomalies 2 days before N. American LRT ${ }^{+}$events for 2004-2010. Top: sea level pressure anomalies (filled contours) and surface wind fields (arrows). Bottom: $850 \mathrm{hPa}$ wind speed anomalies (filled contours) and wind fields (arrows).

regressed modeled summertime CO fluxes out of N. America with SLP, finding a very similar negative SLP anomaly over the Gulf of Saint Lawrence.

\subsection{Evolution of $\mathrm{LRT}^{+}$spring export events over the North Atlantic Ocean}

Once over the Atlantic Ocean, pollution transport is controlled by the strength and position of the Azores High and the Icelandic Low (Auvray and Bey, 2005; Owen et al., 2006). Fig. 10 follows the evolution of composite spring outflow events from N. America over an 8 day period: from 2 days prior to $\mathrm{LRT}^{+}$to 6 days after $\mathrm{LRT}^{+}$. We show fine mode AOD anomalies (expressed as percentage enhancement relative to seasonal values) to highlight pollution outflow. As the composite outflow plume travels over the N. Atlantic Ocean, it is stretched to the NE, following the south westerly winds in the storm track (LRT ${ }^{+}+1$ day). Starting 2 days after $\mathrm{LRT}^{+}$, we see one branch continuing to the NE, reaching Europe on $\mathrm{LRT}^{+}+2-3$ days, while another branch is entrained in the Azores High turning anticyclonically (LRT ${ }^{+}$ plus 3-6 days). These two branches are indicated by thick black arrows and can also be seen in the MODIS fine AOD anomaly composites (Fig. 10b). Such transatlantic transport events have been observed at the PICO-NARE station in the Azores Islands (Honrath et al., 2004; Owen et al., 2006). Auvray and Bey (2005) noted that part of the recirculating
N. American plume in the Azores High can also head back toward Europe.

\subsection{Differences in the vertical profiles of sulfate in E. Asian and N. American outflows}

Figure 11 compares the modeled vertical profiles of sulfate aerosol extinction in the Asian and N. American outflow regions on $\mathrm{LRT}^{+}$days composited by season. To emphasize the vertical structure, we have normalized the profiles by the maximum extinction values, which typically occur at $\sim 1 \mathrm{~km}$ altitude. In the boundary layer (below $2 \mathrm{~km}$ altitude) the profiles in the two outflow regions are similar, however the profiles differ significantly in the free troposphere. In the Asian outflow region a larger fraction of the sulfate is found at higher altitudes, especially during spring and winter. The fraction of column sulfate present in the free troposphere above $2 \mathrm{~km}$ altitude for the Asian outflow (N. American outflow) is: $54 \%$ (35\%), $40 \%$ (24\%), $42 \%$ (25\%), $59 \%$ (32\%) in MAM, JJA, SON, DJF, respectively. Thus in the Asian outflow more than half of the sulfate export occurs above $2 \mathrm{~km}$ altitude during winter and spring. In contrast, in the N. American outflow only a third of the outflow reaches these altitudes.

These differences in the vertical distribution of sulfate aerosols could be due to less efficient scavenging of $\mathrm{SO}_{2}$ and sulfate during export from the boundary layer to the 
a) Evolution of composite AOD anomalies: GEOS-Chem

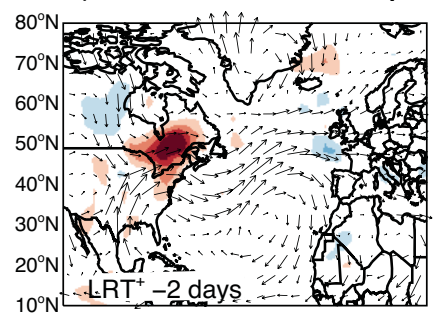

${ }^{80} 0^{\circ} \mathrm{N}$

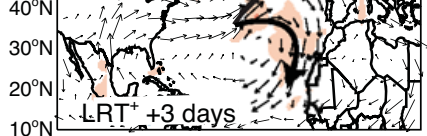

$10^{\circ} \mathrm{N}$ LRT $\mathrm{T}^{+}+3$ days
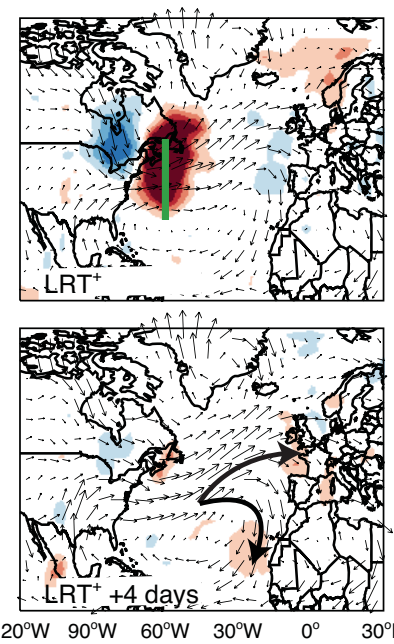
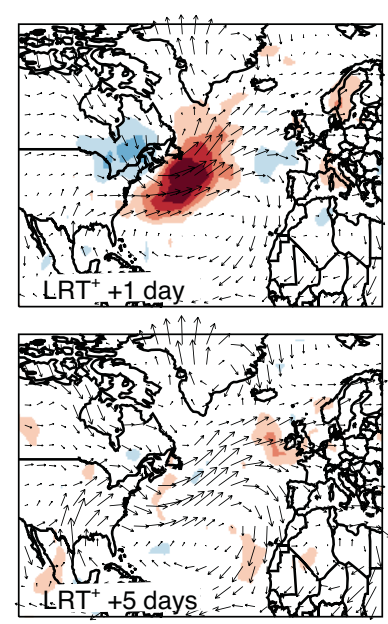

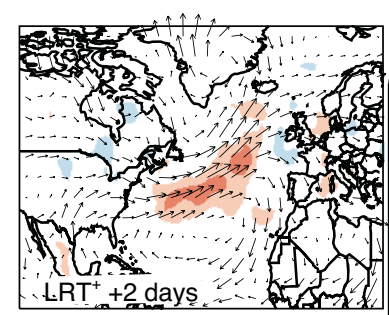

$\%$

50

30

10

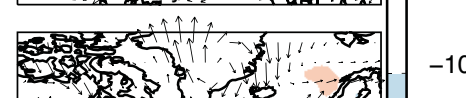

$-10$

$-30$

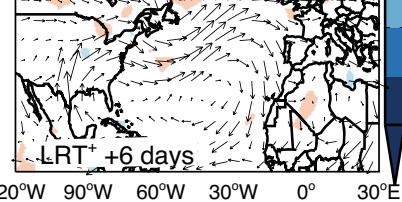

50

\section{b) Evolution of composite AOD anomalies: MODIS}
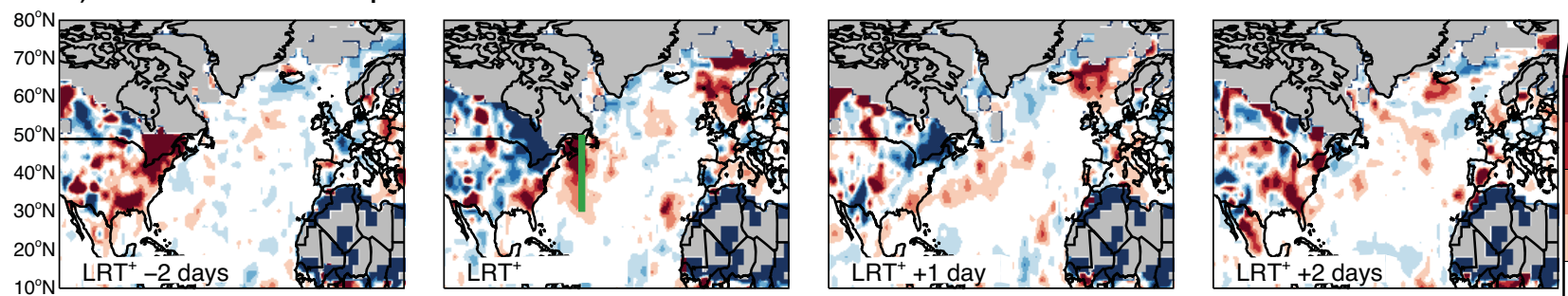

$\%$

50

30
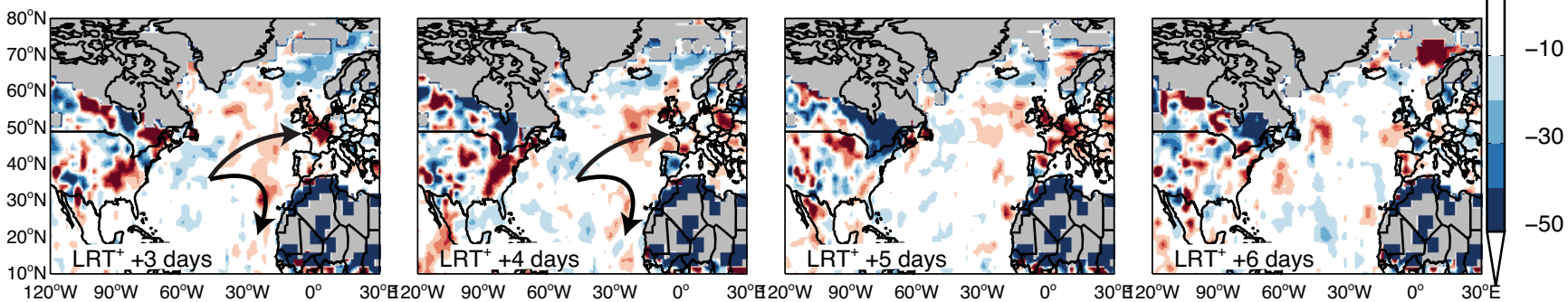

Fig. 10. Springtime evolution of AOD anomalies from 2 days prior to $\mathrm{LRT}^{+}$days to 6 days after $\mathrm{LRT}^{+}$days over the N. Atlantic. The AOD anomalies are expressed in percent relative to seasonal mean AOD values. (a) GEOS-Chem AOD anomalies. Arrow indicated composites of $850 \mathrm{hPa}$ wind fields. (b) MODIS AOD anomalies.

free troposphere off E. Asia compared to N. America. Indeed, mean annual precipitation in the eastern US is about 3-4 mm day ${ }^{-1}$, much higher than over East China at $1-2 \mathrm{~mm} \mathrm{day}^{-1}$ (Fig. 11). While precipitation in the eastern US displays little seasonal variability, precipitation in NE China occurs mostly during summer months. Domrös and Peng (1988) report that $70 \%$ of annual precipitation over NE China takes place in June-July-August. During summer, both regions have similar precipitation rates: $2-$ $3 \mathrm{~mm}$ day $^{-1}$. However, during spring, the NE US experiences 2-3 mm day ${ }^{-1}$, but NE China sees only $1 \mathrm{~mm} \mathrm{day}^{-1}$ (Fig. 11, middle panels). For fall and winter, precipitation over NE China is generally below $1 \mathrm{~mm} \mathrm{day}^{-1}$, while over the NE US it remains at $2-3 \mathrm{mmday}^{-1}$. We further contrast these two regions by examining composites of precipitation two days before spring $\mathrm{LRT}^{+}$events (Fig. 11, bottom panels). The region where we found maximum AOD anomalies (Figs. 6 and 10 ) is highlighted with a box in Fig. 11. Mean precipitation in that box is $1.1 \mathrm{~mm} \mathrm{day}^{-1}$ over E. Asia, but $2.1 \mathrm{~mm} \mathrm{day}^{-1}$ over N. America. Even larger differences are found in fall (E. Asia: $0.4 \mathrm{~mm} \mathrm{day}^{-1}$; N. America: $1.8 \mathrm{~mm} \mathrm{day}^{-1}$ ) and winter (E. Asia: $0.4 \mathrm{~mm}_{\text {day }}{ }^{-1}$; N. America: $2.1 \mathrm{~mm} \mathrm{day}^{-1}$ ). Summer is the only season where precipitation in E. Asia reaches levels comparable to those over N. America (2$3 \mathrm{~mm} \mathrm{day}^{-1}$ ), as a result of the summer monsoon.

Asian midlatitude cyclones in all seasons are usually associated with strong surface winds but little precipitation, because the warm sector of the cyclone is from the dry interior 

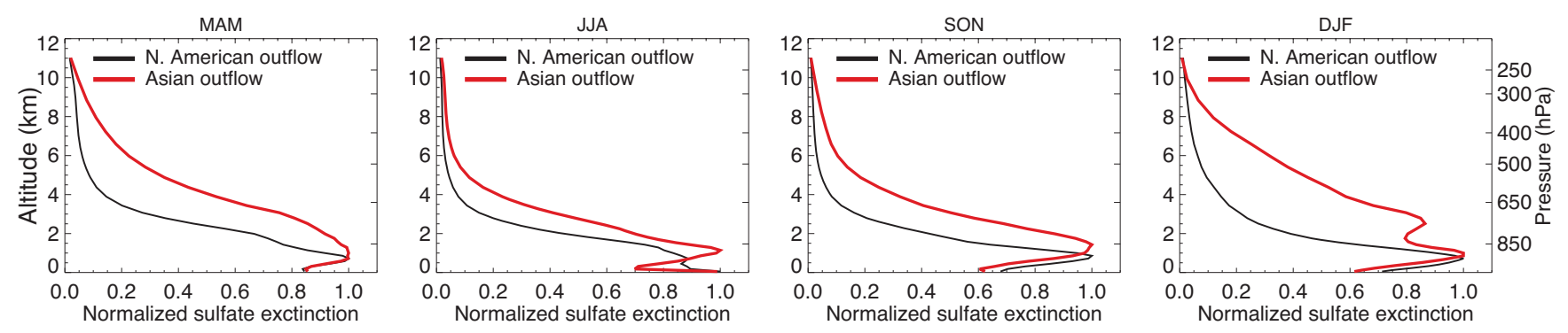

Fig. 11. Seasonal composite of GEOS-Chem sulfate extinction profiles on $\mathrm{LRT}^{+}$days in the outflow regions of N. America $\left(30-50^{\circ} \mathrm{N}\right.$, $60^{\circ} \mathrm{W}$, black line) and $\mathrm{E}$. Asia $\left(30-60^{\circ} \mathrm{N}, 150^{\circ} \mathrm{E}\right.$, red line). The sulfate extinction profiles are normalized by the maximum extinction values for each season. From left to right: MAM, JJA, SON, DJF.

of China, where there is little moisture (Domrös and Peng, 1988). Eckhardt et al. (2004) examined global annual precipitation generated along WCB trajectories, also finding much drier conditions in WCB over E. Asia and the western Pacific Ocean $\left(100^{\circ} \mathrm{E}-150^{\circ} \mathrm{E}\right)$ compared to Eastern N. America and the West Atlantic Ocean $\left(-100^{\circ} \mathrm{E}\right.$ to $-50^{\circ} \mathrm{E}$, see their Fig. 11d). It thus appears the relative dryness of Asian cyclones makes them efficient systems for lifting aerosols and their precursors to the free troposphere over NE China.

There is significant observational evidence that a sizeable fraction of $\mathrm{SO}_{2}$ over China can escape scavenging during lifting and then be converted to sulfate in the free troposphere during transpacific transport. Aircraft measurements over central China in April 2008 displayed very large concentrations of $\mathrm{SO}_{2}$ in the free troposphere, with distinct $\mathrm{SO}_{2}$ plumes observed at $2-4 \mathrm{~km}$ altitude reaching levels of 2-7 ppbv (He et al., 2012). Background free tropospheric $\mathrm{SO}_{2}$ levels were about 1 ppbv over that region. Dickerson et al. (2007) also reported significant levels of $\mathrm{SO}_{2}$ over $\mathrm{NE}$ China, with $0.6 \mathrm{ppbv}$ on average at $2.5 \mathrm{~km}$ altitude. $\mathrm{SO}_{2}$ profiles over the Yellow Sea show distinct layers at $\sim 0.5 \mathrm{~km}$ and $1.5 \mathrm{~km}$ altitude with peaks reaching $3 \mathrm{ppbv}$ (Kline et al., 2004). In contrast, Taubman et al. (2006) and Henningan et al. (2006) measured $0.1-0.2 \mathrm{ppbv}$ mean $\mathrm{SO}_{2}$ concentrations at $2.5 \mathrm{~km}$ during summer over the NE US. Dickerson et al. (2007) proposed that the high levels of $\mathrm{SO}_{2}$ above China during spring could be due to dry convection ahead of cold fronts lofting $\mathrm{SO}_{2}$ from the polluted boundary layer to the free troposphere with little scavenging. Using the OMI instrument onboard the Aura satellite, Li et al. (2010) followed the evolution of $\mathrm{S} \mathrm{SO}_{2}$ plume from NE China to the NW Pacific Ocean, finding a $\sim 2$ day e-folding time for $\mathrm{SO}_{2}$. The resulting conversion of $\mathrm{SO}_{2}$ to sulfate led to an increase in MODIS AOD by $0.1-0.4$ in the plume over the NW Pacific Ocean. Using in situ aircraft measurements, Brock et al. (2004) reported enhanced levels of sulfate aerosols and gas-phase $\mathrm{H}_{2} \mathrm{SO}_{4}$ in an Asian plume intercepted off California Coast. Dunlea et al. (2009) presented two case studies of Asian plumes observed over the NE Pacific Ocean at 3-6 km altitude during spring 2006. One of the plumes was inter- cepted 3-4 days downwind of Asia, with $2.4 \mathrm{ppbv} \mathrm{SO}_{2}$ and $50 \%$ of the sulfur present at sulfate. An older plume, 7-10 days downwind of Asia, had less $\mathrm{SO}_{2}(0.1 \mathrm{ppbv})$, but more sulfur present as sulfate $(90 \%)$.

Our model simulations suggest that the relative lack of precipitation in WCBs over E. Asia leads to more efficient export of $\mathrm{SO}_{2}$ and sulfate to the free troposphere compared to N. America. During winter, an additional factor could be that larger $\mathrm{SO}_{2}$ emissions over E. Asia result in the titration of $\mathrm{H}_{2} \mathrm{O}_{2}$ by in-cloud $\mathrm{SO}_{2}$ oxidation to sulfate aerosols (Chin and Jacob, 1996; Tu et al., 2004). As the availability of $\mathrm{H}_{2} \mathrm{O}_{2}$ is one of the limits to aqueous $\mathrm{SO}_{2}$ uptake, this could lead to more efficient export of $\mathrm{SO}_{2}$, especially during winter when oxidant levels are low.

\section{Summary}

We used MODIS observations of AOD combined with the GEOS-Chem chemical transport model to analyze outflow of aerosols out of E. Asia and N. America in 2004-2010. Compared to MODIS, the GEOS-Chem model reproduces the spatial distribution and temporal variation of Asian and $\mathrm{N}$. American aerosol outflow reasonably well in general. However, GEOS-Chem underestimates MODIS fine AOD by $30 \%$ over the N. Pacific and N. Atlantic Oceans. This negative bias is largest during summer and could be related to too low fire injection heights in the model, or possibly to a missing oceanic source of aerosols in the model. During the 7 years of our study period, we have identified 244 aerosol outflow events from E. Asia (81 in spring, 47 in summer, 56 in fall, 60 in winter) and 251 events from N. America (72 in spring, 60 in summer, 61 in fall, 58 in winter) using the modeled sulfate AOD as a proxy for pollution aerosols. We have composited these enhanced outflow events (LRT ${ }^{+}$events) by season to examine common patterns in aerosol enhancements and meteorological fields. For both outflow regions and across all seasons, we find a 50-100\% AOD enhancement during $\mathrm{LRT}^{+}$events relative to seasonal mean AOD levels. We found that $2 / 3$ of the E. Asian sulfate aerosol ex- 

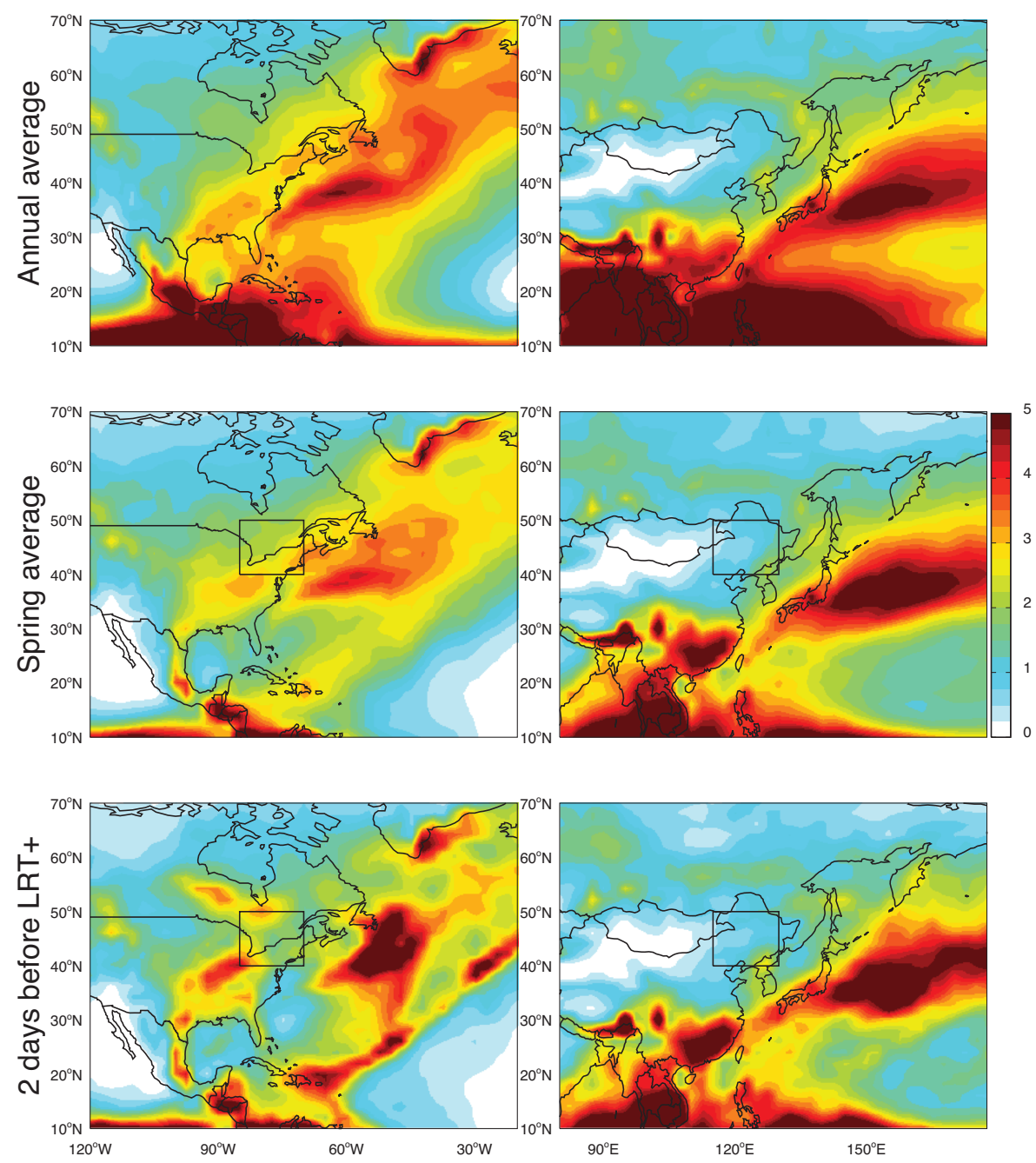

Fig. 12. Comparison of GEOS-5 precipitation in N. America (left) and E. Asia (right) (unit: mm day ${ }^{-1}$ ). Top: Annual mean for $2004-2010$. Middle panel: Spring mean for 2004-2010. Bottom panel: composite of springtime RRT $^{+}$days with a 2 day lag. The box in the middle and bottom panels indicates the location of maximum AOD enhancement.

port events during spring are associated with substantial dust export.

In spring, fall and winter, both the E. Asian aerosol outflow and the N. American outflow are favored by a dipole structure in SLP anomalies two days prior to $\mathrm{LRT}^{+}$events. Over E. Asia, this dipole is composed of negative SLP anomalies over NE China and positive SLP anomalies over the Sea of Japan and the East China Sea, accompanied by strong convergent winds and upward motion over NE China. Over $\mathrm{N}$. America, the dipole is characterized by negative SLP anomalies over central N. America and positive SLP anomalies over the NW Atlantic, associated with strong convergent winds over the Great Lakes region. This surface SLP signature indicates that midlatitude cyclones are the dominant synoptic scale influence on export of pollution from both regions. During summer the negative SLP anomaly is much weaker, likely because other meteorological factors, such as convective storms, are the dominant export mechanism.

We followed the evolution of composite spring export events over the N. Pacific and N. Atlantic Oceans. The modeled AOD composite plume maintained coherence over an 8-day period as it crossed the ocean basins, illustrating the common features of the individual long-range transport events. The MODIS AOD composites did not show much coherence because of frequent cloud cover and thus patchy sampling of the plumes by the satellite. We found that after export over the NW Pacific Ocean, the aerosol plume splits into two branches. One branch is transported to the Arctic when a blocking high pressure system is present in the central N. Pacific Ocean. The other branch continues in the westerly winds, reaching N. America 6-8 days after leaving E. China. The resulting column AOD enhancement is 10-20\% over the west coast of N. America. Part of the aerosol pollution plume 
recirculates in the Pacific High. The N. American composite pollution plume follows two distinctive pathways over the N. Atlantic Ocean: one transport pathway reaches Europe after 4-5 days, while the other pathway is entrained in the Azores High, turning anticyclonically.

We found that the E. Asian aerosol outflow differs from N. American aerosol outflow in several aspects. MODIS annual mean AOD over the NW Pacific Ocean is about $40 \%$ larger than AOD over the NW Atlantic Ocean. During spring, AOD over the NW Pacific Ocean is nearly a factor of 2 higher than over the NW Atlantic Ocean. Some of this enhancement is due to the combination of higher anthropogenic emissions of aerosol precursors over E. Asia together with significant dust emissions. By examining vertical profiles of model aerosol extinction coefficients in the outflow regions, we found that $65-76 \%$ of the N. American sulfate aerosol column is confined to altitudes below $2 \mathrm{~km}$. However, in the E. Asian outflow $41-60 \%$ of the sulfate aerosol is found below $2 \mathrm{~km}$, with a significant fraction occurring at 2-6 km altitude. During winter and spring, our model results suggest that $54-59 \%$ of the sulfate aerosol column in the Asian outflow occurs above $2 \mathrm{~km}$ altitude, compared to only 32-34\% in the N. American outflow. We linked this more efficient export to the free troposphere over E. Asia to the fact that midlatitude cyclone precipitation over northern China is inhibited during the dry monsoon season (winter and spring), while precipitation over Eastern N. America occurs all-year round. The factor of 2-3 difference in precipitation results in less scavenging during aerosol export episodes over E. Asia than over N. America, suggesting more efficient export by mid-latitude cyclones over E. Asia and thus a larger propensity for intercontinental transport.

Acknowledgements. This work was supported by funding from the NASA Atmospheric Composition Modeling and Analysis Program under awards NNX08AK49G and NNX11AL74G. This paper has benefited from discussions with Mike Wallace. We acknowledge the MODIS science team for the production of the data used in this analysis.

Edited by: J. West

\section{References}

Andreae, M. O., Berresheim, H., Andreae, T. W., Kritz, M. A., Bates, T. S., Merrill, J.T.: Vertical distribution of dimethylsulfide, sulfur dioxide, aerosol ions, and radon over the northeast Pacific Ocean, J. Atmos. Chem., 6, 149-173, 1998.

Angevine, W. M., Buhr, M. P., Holloway, J. S., Trainer, M., Parrish, D. D., MacPherson, J. I., Kok, G. L., Schillawski, R. D., and Bowlby, D. H.: Local meteorological features affecting chemical measurements at a north Atlantic coastal site, J. Geophys. Res., 101, 28935-28946, 1996.
Arimoto, R., Duce, R. A., Savoie, D. L., Prospero, J. M., Talbot, R., Cullen, J. D., Tomza, U., Lewis, N. F., and Jay, B. J.: Relationships among aerosol constituents from Asia and the North Pacific during PEM-West A, J. Geophys. Res., 101, 2011-2023, 1996.

Arimoto, R., Duce, R. A., Prospero, J. M., Savoie, D. L., Talbot, R. W., Dibb, J. E., Heikes, B. G., Ray, B. J., Lewis, N. F., and Tomza, U.: Comparisons of trace constituents from ground stations and the DC- 8 aircraft during PEM-West B, J. Geophys. Res., 102, 28539-28550, 1997.

Auvray, M. and Bey, I.: Long-range transport to Europe: seasonal variations and implications for the European ozone budget, J. Geophys. Res., 110, D11303, doi:10.1029/2004JD005503, 2005.

Bahreini, R., Jimenez, J., Wang, J., Flagan, R., Seinfeld, J., Jayne, J., and Worsnop, D.: Aircraft-based aerosol size and composition measurements during ACE-Asia using an Aerodyne aerosol mass spectrometer, J. Geophys. Res.-Atmos., 108, 8645, doi:10.1029/2002JD003226, 2003.

Benkovitz, C. M., Schwartz, S. E., and Kim, B.-G.: Evaluation of a chemical transport model for sulfate using ACE-2 observations and attribution of sulfate mixing ratios to source regions and formation processes, Geophys. Res. Lett., 30, 1641, doi:10.1029/2003GL016942, 2003.

Bertschi I. T. and Jaffe, D. A.: Long-range transport of ozone, carbon monoxide, and aerosols to the NE Pacific troposphere during the summer of 2003: observations of smoke plumes from Asian boreal fires, J. Geophys. Res., 110, D05303, doi:10.1029/2004JD005135, 2005.

Bertschi, I. T., Jaffe, D. A., Jaegle, L., Price, H. U., and Dennison, J. B.: PHOBEA/ITCT 2002 airborne observations of transpacific transport of ozone, $\mathrm{CO}$, volatile organic compounds, and aerosols to the northeast Pacific: impacts of Asian anthropogenic and Siberian boreal fire emissions, J. Geophys. Res., 109, D23S12, doi:10.1029/2003JD004328, 2004.

Bey, I., Jacob, D. J., Logan, J. A., and Yantosca, R. M.: Asian chemical outflow to the Pacific in spring: Origins, pathways, and budgets, J. Geophys. Res., 106, 23097-23113, doi:10.1029/2001JD000806, 2001a.

Bey, I., Jacob, D. J., Yantosca, R. M., Logan, J. A., Field, B. D., Fiore, A. M., Li, Q., Liu, H. Y., Mickley, L. J., and Schultz, M.G.: Global modeling of tropospheric chemistry with assimilated meteorology- Model description and evaluation, J. Geophys. Res., 106, 073-23,095, 2001b.

Brock, C. A., Hudson, P. K., Lovejoy, E. R., Sullivan, A., Nowak, J. B., Huey, L. G., Cooper, O. R., Cziczo, D. J., de Gouw, J., Fehsenfeld, F. C., Holloway, J. S., Hubler, G., Lafleur, B. G., Murphy, D. M., Neuman, J. A., Nicks, D. K., Orsini, D. A., Parrish, D. D., Ryerson, T. B., Tanner, D. J., Warneke, C., Weber, R. J., and Wilson, J. C.: Particle characteristics following cloud-modified transport from Asia to North America, J. Geophys. Res., 109, D23S26, doi:10.1029/2003JD004198, 2004.

Chen, S.-J., Kuo, Y.-H., Zhang, P.-Z., and Bai, Q.-F.: Synoptic Climatology of Cyclogenesis over East Asia, 1958-1987, Mon. Wea. Rev., 119, 1407-1418, 1991.

Chin, M. and Jacob, D. J.: Anthropogenic and natural contributions to tropospheric sulfate: A global model analysis, J. Geophys. Res., 101, 18691-18699, doi:10.1029/96JD01222, 1996.

Clarke, A. D., Collins, W. G., Rasch, P. J., Kapustin, V. N., Moore, K., Howell, S., and Fuelberg, H. E.: Dust and pollution transport on global scales: Aerosol measurements and model predictions, 
J. Geophys. Res., 106, 32555-32569, 2001.

Clarisse, L., Fromm, M., Ngadi, Y., Emmons, L., Clerbaux, C., Hurtmans, D., and Coheur, P.-F.: Intercontinental transport of anthropogenic sulfur dioxide and other pollutants: An infrared remote sensing case study, Geophys. Res. Lett., 38, L19806, doi:10.1029/2011GL048976, 2011.

Cooper, O. R., Moody, J. L., Parrish, D. D., Trainer, M., Ryerson, T. B., Holloway, J. S., Hübler, G., Fehsenfeld, F. C., Oltmans, S. J., and Evans, M. J.: Trace gas signatures of the airstreams within North Atlantic cyclones: Case studies from the North Atlantic Regional Experiment (NARE '97) aircraft intensive, J. Geophys. Res., 106, 5437-5456, doi:10.1029/2000JD900574, 2001.

Cooper, O., Moody, J., Parrish, D., Trainer, M., Ryerson, T., Holloway, J., Hübler, G., Fehsenfeld, F., and Evans, M.: Trace gas composition of midlatitude cyclones over the western North Atlantic Ocean: A conceptual model, J. Geophys. Res., 107, 4056, 2002.

Cooper, O. R., Forster, C., Parrish, D., Trainer, M., Dunlea, E., Ryerson, T., Hubler, G., Fehsenfeld, F., Nicks, D., Holloway, J., de Gouw, J., Warneke, C., Roberts, J. M., Flocke, F., and Moody, J.: A case study of transpacific warm conveyor belt transport: Influence of merging airstreams on trace gas import to North America, J. Geophys. Res., 109, D23S08, doi:10.1029/2003JD003624, 2004.

Dickerson, R. R., Li, C., Li, Z., Marufu, L. T., Stehr, J. W., McClure, B., Krotkov, N., Chen, H., Wang, P., Xia, X., Ban, X., Gong, F., Yuan, J., and Yang, J.: Aircraft observations of dust and pollutants over northeast China: Insight into the meteorological mechanisms of transport, J. Geophys. Res, 112, D24S90, 2007.

Daum, P. H., Kleinman, L. I., Newman, L., Luke, W. T., WeinsteinLloyd, J., Berkowitz, C. M., and Busness, K. M.: Chemical and physical properties of plumes of anthropogenic pollutants transported over the North Atlantic during the North Atlantic Regional Experiment, J. Geophys. Res., 101, 29029-29042, doi:10.1029/95JD03163, 1996.

Domrös, M. and Peng, G.: The climate of China, Springer-Verlag, Berlin, Germany, 1988.

Drury, E., Jacob, D. J., Spurr, R. J. D., Wang, J., Shinozuka, Y., Anderson, B. E., Clarke, A. D., Dibb, J., McNaughton, C., and Weber, R.: Synthesis of satellite (MODIS), aircraft (ICARTT), and surface (IMPROVE, EPA-AQS, AERONET) aerosol observations over eastern North America to improve MODIS aerosol retrievals and constrain surface aerosol concentrations and sources, J. Geophys. Res., 115, D14204, doi:10.1029/2009JD012629, 2010.

Duce, R. A., Unni, C. K., Ray, B. J., Prospero, J. M., and Merrill, J. T.: Long-Range Atmospheric Transport of Soil Dust from Asia to the Tropical North Pacific: Temporal Variability, Science, 209, 1522-1524, 1980.

Dunlea, E. J., DeCarlo, P. F., Aiken, A. C., Kimmel, J. R., Peltier, R. E., Weber, R. J., Tomlinson, J., Collins, D. R., Shinozuka, Y., McNaughton, C. S., Howell, S. G., Clarke, A. D., Emmons, L. K., Apel, E. C., Pfister, G. G., van Donkelaar, A., Martin, R. V., Millet, D. B., Heald, C. L., and Jimenez, J. L.: Evolution of Asian aerosols during transpacific transport in INTEX-B, Atmos. Chem. Phys., 9, 7257-7287, doi:10.5194/acp-9-7257-2009, 2009.

Eckhardt, S., Stohl, A., Wernli, H., James, P., and Forster, C.: Spichtinger, N.: A 15-Year Climatology of Warm Conveyor
Belts, J. Climate, 17, 218-237, 2004.

Eguchi, K., Uno, I., Yumimoto, K., Takemura, T., Shimizu, A., Sugimoto, N., and Liu, Z.: Trans-pacific dust transport: integrated analysis of NASA/CALIPSO and a global aerosol transport model, Atmos. Chem. Phys., 9, 3137-3145, doi:10.5194/acp-93137-2009, 2009.

Fairlie, T. D., Jacob, D. J., and Park, R. J.: The impact of transpacific transport of mineral dust in the United States, Atmos. Environ., 41, 1251-1266, 2007.

Fairlie, T. D., Jacob, D. J., Dibb, J. E., Alexander, B., Avery, M. A., van Donkelaar, A., and Zhang, L.: Impact of mineral dust on nitrate, sulfate, and ozone in transpacific Asian pollution plumes, Atmos. Chem. Phys., 10, 3999-4012, doi:10.5194/acp-10-39992010, 2010.

Fang, Y., Fiore, A. M., Horowitz, L. W., Gnanadesikan, A., Levy II, H., Hu, Y., and Russell, A. G.: Estimating the contribution of strong daily export events to total pollutant export from the United States in summer, J. Geophys. Res., 114, D23302, doi:10.1029/2008JD010946, 2009.

Fehsenfeld, F., Ancellet, G., Bates, T., Goldstein, A., Hardesty, R., Honrath, R., Law, K., Lewis, A., Leaitch, R., and McKeen, S.: International Consortium for Atmospheric Research on Transport and Transformation (ICARTT): North America to Europe Overview of the 2004 summer field study, J. Geophys. Res, 111, D23S01, 1522-1524, 2006.

Forster, C., Wandinger, U., Wotawa, G., James, P., Mattis, I., Althausen, D., Simmonds, P., O’Doherty, S., Jennings, S.G., Kleefeld, C., Schneider, J., Trickl, T., Kreipl, S., Jäger, H., and Stohl, A.: Transport of boreal forest fire emissions from Canada to Europe, J. Geophys. Res., 106, 22887-22906, 2001.

Fu, T.-M., Jacob, D. J., Palmer, P. I., Chance, K., Wang, Y. X., Barletta, B., Blake, D. R., Stanton, J. C., and Pilling, M. J.: Space-based formaldehyde measurements as constraints on volatile organic compound emissions in east and south Asia and implications for ozone, J. Geophys. Res., 112, D06312, doi:10.1029/2006JD007853, 2007.

Goldstein, A. H., Koven, C. D., Heald, C. L., and Fung, I.: Biogenic carbon and anthropogenic pollutants combine to form a cooling haze over the southeastern US, Proc. Nat. Acad. Sci., 106, 88358840, 2009.

Guenther, A., Hewitt, N., Erickson, D., Fall, R., Geron, C., Graedel, T., Harley, P., Klinger, L., Lerdau, M., McKay, W., Pierce, T., Scholes, B., Steinbrecher, R., Tallamraju, R., Taylor, J., and Zimmerman, P.: A global model of natural volatile organic compound emissions, J. Geophys. Res., 100, 8873-8892, 1995.

Guerova, G., Bey, I., Attié, J.-L., Martin, R. V., Cui, J., and Sprenger, M.: Impact of transatlantic transport episodes on summertime ozone in Europe, Atmos. Chem. Phys., 6, 2057-2072, doi:10.5194/acp-6-2057-2006, 2006.

He, H., Li, C., Loughner, C. P., Li, Z., Krotkov, N. A., Yang, K., Wang, L., Zheng, Y., Bao, X., Zhao, G., Dickerson, R.R.: $\mathrm{SO}_{2}$ over central China: Measurements, numerical simulations and the tropospheric sulfur budget, J. Geophys. Res., 117, D00K37, doi:10.1029/2011JD016473, 2012.

Heald, C. L., Jacob, D. J., Park, R. J., Russel, L. M., Huebert, B. J., Seinfeld, J. H., Liao, H., and Weber, R.: A large organic aerosol source in the free troposphere missing from current models, Geophys. Res. Let., 32, L18809, doi:10.1029/2005GL023831, 2005. 
Heald, C. L., Jacob, D. J., Park, R. J., Alexander, B., Fairlie, T. D., Yantosca, R. M., and Chu, D. A.: Transpacific transport of Asian anthropogenic aerosols and its impact on surface air quality in the United States, J. Geophys. Res., 111, D14310, doi:10.1029/2005JD006847, 2006a.

Heald, C. L., Jacob, D. J., Turquety, S., Hudman, R. C., Weber, R. J., Sullivan, A. P., Peltier, R. E., Atlas, E. L., de Gouw, J. A., Warneke, C., Holloway, J. S., Neuman, J. A., Flocke, F. M., and Seinfeld, J. H.: Concentrations and sources of organic carbon aerosol in the free troposphere over North America, J. Geophys. Res., 111, D23S47, doi:10.1029/2006JD007705, 2006 b.

Hennigan, C. J., Sandholm, S., Kim, S., Stickel, R. E., Huey, L. G., and Weber, R. J.: Influence of Ohio River valley emissions on fine particle sulfate measured from aircraft over large regions of the eastern United States and Canada during INTEX-NA, J. Geophys. Res., 111, D24S04, doi:10.1029/2006JD007282, 2006.

Hoell, J., Davis, D., Liu, S., Newell, R., Shipham, M., Akimoto, H., McNeal, R., Bendura, R., and Drewry, J.: Pacific Exploratory Mission-West A (PEM-West A): September-October 1991, J. Geophys. Res, 101, 1641-1653, 1996.

Hoell, J., Davis, D., Liu, S., Newell, R., Akimoto, H., McNeal, R., and Bendura, R.: The Pacific exploratory mission-west phase B: February-March, 1994, J. Geophys. Res. D. Atmos., 102, 2822328239, 1997.

Holzer, M., McKendry, I. G., and Jaffe, D. A.: Springtime trans-Pacific atmospheric transport from East Asia: A transit-time-pdf approach, J. Geophys. Res., 108, 4708, doi:10.1029/2003JD003558, 2003.

Holzer, M., Hall, T. M., and Stull, R. B.: Seasonality and weatherdriven variability of transpacific transport, J. Geophys. Res., 110, D23103, doi:10.1029/2005JD006261, 2005.

Honrath, R. E., Owen, R. C., Val Martin, M., Reid, J. S., Lapina, K., Fiahlo, P., Dziobak, M. P., Kleissel, J., and Westphal, D. L.: Regional and hemispheric impacts of anthropogenic and biomass burning emissions on summertime $\mathrm{CO}$ and $\mathrm{O}_{3}$ in the North Atlantic lower free troposphere, J. Geophys. Res.-Atmos., 109, D24310, doi:10.1029/2004JD005147, 2004.

Hsu, N.C., Tsay, S.C., King, M.D., Herman, J.R.: Deep blue retrievals of Asian aerosol properties during ACE-Asia, IEEE Trans., 44, 3180-3195, 2006.

Hsu, N. C., Li, C., Krotkov, N. A., Liang, Q., Yang, K., and Tsay, S.-C.: Rapid transpacific transport in autumn observed by the A-train satellites, J. Geophys. Res., 117, D06312, doi:10.1029/2011JD016626, 2012.

Huang, J. P., Minnis, B., Chen, Z., Huang, Z., Liu, Q., Zhao, Y., Yi, and Ayers, J. K.: Long-range transport and vertical structure of Asian dust from CALIPSO and surface measurements during PACDEX, J. Geophys. Res., 113, D23212, doi:10.1029/2008JD010620, 2008.

Huebert, B. J., Bates, T., Russell, P. B., Shi, G., Kim, Y. J., Kawamura, K., Carmichael, G., and Nakajima, T.: An overview of ACE-Asia: Strategies for quantifying the relationships between Asian aerosols and their climatic impacts, J. Geophys. Res., 108, 8633, doi:10.1029/2003JD003550, 2003.

Huntrieser, H., Heland, J., Schlager, H., Forster, C., Stohl, A., Aufmhoff, H., Arnold, F., Scheel, H. E., Campana, M., Gilge, S., Eixmann, R., and Cooper, O.: Intercontinental air pollution transport from North America to Europe: Experimental evidence from airborne measurements and surface observations, J. Geo- phys. Res., 110, D01305, doi:10.1029/2004JD005045, 2005.

Husar, R. B., Tratt, D. M., Schichtel, B. A., Falke, S. R., Li, F., Jaffe, D., Gassó, S., Gill, T., Laulainen, N. S., Lu, F., Reheis, M. C., Chun, Y., Westphal, D., Holben, B. N., Gueymard, C., McKendry, I., Kuring, N., Feldman, G. C., McClain, C., Frouin, R. J., Merrill, J., DuBois, D., Vignola, F., Murayama, T., Nickovic, S., Wilson, W. E., Sassen, K., Sugimoto, N., and Malm, W. C.: Asian dust events of April 1998, J. Geophys. Res., 106, 18,317-18,330, doi:10.1029/2000JD900788, 2001.

Jacob, D. J., Crawford, J. H., Kleb, M. M., Connors, V. S., Bendura, R. J., Raper, J. L., Sachse, G. W., Gille, J. C., Emmons, L., and Heald, C. L.: Transport and Chemical Evolution over the Pacific (TRACE-P) aircraft mission: Design, execution, and first results, J. Geophys. Res, 108, 9000, doi:10.1029/2002JD003276, 2003.

Jaeglé, L., Jaffe, D. A., Price, H. U., Weiss-Penzias, P., Palmer, P. I., Evans, M. J., Jacob, D. J., and Bey, I.: Sources and budgets for $\mathrm{CO}$ and $\mathrm{O}_{3}$ in the Northeast Pacific during the spring of 2001: Results from the PHOBEA-II Experiment, J. Geophys.Res., 108, 8802, doi:10.1029/2002JD003121, 2003.

Jaeglé, L., Quinn, P. K., Bates, T. S., Alexander, B., and Lin, J.-T.: Global distribution of sea salt aerosols: new constraints from in situ and remote sensing observations, Atmos. Chem. Phys., 11, 3137-3157, doi:10.5194/acp-11-3137-2011, 2011.

Jaffe, D., Anderson, T., Covert, D., Kotchenruther, R., Trost, B., Danielson, J., Simpson, W., Berntsen, T., Karlsdottir, S., and Blake, D.: Transport of Asian Air Pollution to North America, Geophys. Res. Lett., 26, 711-714, 1999.

Jaffe, D., Anderson, T., Covert, D., Trost, B., Danielson, J., Simpson, W., Blake, D., Harris, J., and Streets, D.: Observations of ozone and related species in the northeast Pacific during the PHOBEA campaigns 1. Ground-based observations at Cheeka Peak, J. Geophys. Res., 106, 7449-7461, 2001.

Jaffe, D., McKendry, I., Anderson, T., and Price, H.: Six "new" episodes of trans-Pacific transport of air pollutants, Atmos. Environ., 37, 391-404, 2003.

Kaufman, Y. J., Remer, L. A., Tanre, D., Rong-Rong, L., Kleidman, R., Mattoo, S., Levy, R. C., Eck, T. F., Holben, B. N., Ichoku, C., Martins, J. V., and Koren, I.: A critical examination of the residual cloud contamination and diurnal sampling effects on MODIS estimates of aerosol over ocean, Geoscience and Remote Sensing, IEEE Trans. Geosci. Remote Sens., 43, 2886-2897, 2005a.

Kaufman, Y. J., Boucher, O., Tanré, D., Chin, M., Remer, L. A., and Takemura, T.: Aerosol anthropogenic component estimated from satellite data, Geophys. Res. Lett., 32, L17804, doi:10.1029/2005GL023125, 2005b.

Kiley, C. M. and Fuelberg, H. E.: An examination of summertime cyclone transport processes during Intercontinental Chemical Transport Experiment (INTEX-A), J. Geophys. Res., 111, D24S06, doi:10.1029/2006JD007115, 2006.

Kline, J., Huebert, B., Howell, S., Blomquist, B., Zhuang, J., Bertram, T., and Carrillo, J.: Aerosol composition and size versus altitude measured from the C-130 during ACE-Asia, J. Geophys. Res., 109, D19S08, doi:10.1029/2004JD004540, 2004.

Knapp, K. G., Jensen, M. L., Balsley, B. B., Bognar, J. A., Oltmans, S. J., Smith, T. W., and Birks, J. W.: Vertical profiling using a complementary kite and tethered balloon platform at Ferryland Downs, Newfoundland, Canada: Observation of a dry, ozonerich plume in the free troposphere, J. Geophys. Res., 103, 1338913397, doi:10.1029/97JD01831, 1998. 
Kotchenruther, R., Jaffe, D. A., and Jaeglé, L.: Ozone photochemistry and the role of peroxyacetyl nitrate in the springtime northeastern Pacific troposphere- Results from the Photochemical Ozone Budget of the Eastern North Pacific Atmosphere (PHOBEA) campaign, J. Geophys. Res., 106, 283128742, doi:10.1029/2000JD000060, 2001.

Lapina, K., Heald, C. L., Spracklen, D. V., Arnold, S. R., Allan, J. D., Coe, H., McFiggans, G., Zorn, S. R., Drewnick, F., Bates, T. S., Hawkins, L. N., Russell, L. M., Smirnov, A., O’Dowd, C. D., and Hind, A. J.: Investigating organic aerosol loading in the remote marine environment, Atmos. Chem. Phys., 11, 8847-8860, doi:10.5194/acp-11-8847-2011, 2011.

Leung, F. Y. T., Logan, J. A., Park, R., Hyer, E., Kasischke, E., Streets, D., and Yurganov, L.: Impacts of enhanced biomass burning in the boreal forests in 1998 on tropospheric chemistry and the sensitivity of model results to the injection height of emissions, J. Geophys. Res., 112, D10313, doi:10.1029/2006JD008132, 2007.

Levy, R. C., Leptoukh, G. G., Kahn, R., Zubko, V., Gopalan, A., and Remer, L. A.: A Critical Look at Deriving Monthly Aerosol Optical Depth From Satellite Data, IEEE T. Geosci. Remote, 47, 2942-2956, doi:10.1109/TGRS.2009.2013842, 2009.

Levy, R. C., Remer, L. A., Kleidman, R. G., Mattoo, S., Ichoku, C., Kahn, R., and Eck, T. F.: Global evaluation of the Collection 5 MODIS dark-target aerosol products over land, Atmos. Chem. Phys., 10, 10399-10420, doi:10.5194/acp-10-10399-2010, 2010.

Li, C., Krotkov, N. A., Dickerson, R. R., Li, Z., Yang, K., and Chin, M.: Transport and evolution of a pollution plume from northern China: A satellite-based case study, J. Geophys. Res., 115, D00K03, doi:10.1029/2009JD012245, 2010.

Li, Q. B., Jacob, D. J., Park, R. J., Wang, Y. X., Heald, C. L., Hudman, R., Yantosca, R. M., Martin, R. V., and Evans, M. J.: North American pollution outflow and the trapping of convectively lifted pollution by upper-level anticyclone, J. Geophys. Res., 110, D10301, doi:10.1029/2004JD005039, 2005.

Liang, Q., Jaeglé, L., Jaffe, D. A., Weiss-Penzias, P., Heckman, A., and Snow, J. A.: Long-range transport of Asian pollution to the northeast Pacific: Seasonal variations and transport pathways of carbon monoxide, J. Geophys. Res., 109, D23S07, doi:10.1029/2003JD004402, 2004.

Liang, Q., Jaegle, L., and Wallace, J. M.: Meteorological indices for Asian outflow and transpacific transport on daily to interannual timescales, J. Geophys. Res. Atmos., 110, D18308, doi:10.1029/2005jd005788, 2005.

Lin, M., Holloway, T., Carmichael, G. R., and Fiore, A. M.: Quantifying pollution inflow and outflow over East Asia in spring with regional and global models, Atmos. Chem. Phys., 10, 42214239, doi:10.5194/acp-10-4221-2010, 2010.

Liu, H., Jacob, D. J., Bey, I., and Yantosca, R. M.: Constraints from ${ }^{210} \mathrm{~Pb}$ and ${ }^{7} \mathrm{Be}$ on wet deposition and transport in a global threedimensional chemical tracer model driven by assimilated meteorological fields, J. Geophys. Res, 106, 12109-12128, 2001.

Liu, H. Y., Jacob, D. J., Bey, I., Yantosca, R. M., Duncan, B. N., and Sachse, G. W.: Transport pathways for Asian pollution outflow over the Pacific: Interannual and seasonal variations, J. Geophys. Res., 108, 8786, doi:10.1029/2002JD003102, 2003.

Lu, Z., Zhang, Q., and Streets, D. G.: Sulfur dioxide and primary carbonaceous aerosol emissions in China and India, 1996-2010, Atmos. Chem. Phys., 11, 9839-9864, doi:10.5194/acp-11-9839-
2011, 2011.

Martin, R. V., Jacob, D. J., Yantosca, R. M., Chin, M., and Ginoux, P.: Global and regional decreases in tropospheric oxidants from photochemical effects of aerosols, J. Geophys. Res., 108, 4097, doi:10.1029/2002JD002622, 2003.

Matsui, H., Kondo, Y., Moteki, N., Takegawa, N., Sahu, L. K., Zhao, Y., Fuelberg, H. E., Sessions, W., Diskin, G., Blake, D. R., and Wisthaler, A.: Seasonal variation of the transport of black carbon aerosol from the Asian continent to the Arctic during the ARCTAS aircraft campaign, J. Geophys. Res., 116, D05202, doi:10.1029/2010JD015067, 2011.

Merrill, J. T., and Moody, J. L.: Synoptic meteorology and transport during the North Atlantic Regional Experiment (NARE) intensive: Overview, J. Geophys. Res., 101, 28903-28921, doi:10.1029/96JD00097, 1996.

Millet, D. B., Goldstein, A. H., Holzinger, R., Williams, B. J., Allan, J. D., Jimenez, J. L., Worsnop, D. R., Roberts, J. M., White, A. B., Hudman, R. C., Bertschi, I. T., and Stohl, A.: Chemical characteristics of North American surface layer outflow: insights from Chebogue Point, Nova Scotia, J. Geophys. Res., 111, D23S53, doi:10.1029/2006JD007287, 2006.

Millet, D. B., Jacob, D. J., Boersma, K. F., Fu, T.-M., Kurosu, T. P., Chance, K., Heald, C. L., and Guenther, A.: Spatial distribution of isoprene emissions from North America derived from formaldehyde column measurements by the OMI satellite sensor, J. Geophys. Res., 113, D02307, doi:10.1029/2007JD008950, 2008.

Murphy, D. M., Cziczo, D. J., Froyd, K. D., Hudson, P. K., Matthew, B. M., Middlebrook, A. M., Peltier, R. E., Sullivan, A., Thomson, D. S., and Weber, R. J.: Single-particle mass spectrometry of tropospheric aerosol particles, J. Geophys. Res., 111, D23S32, doi:10.1029/2006JD007340, 2006.

Nam, J., Wang, Y., Luo, C., and Chu, D. A.: Trans-Pacific transport of Asian dust and CO: accumulation of biomass burning $\mathrm{CO}$ in the subtropics and dipole structure of transport, Atmos. Chem. Phys., 10, 3297-3308, doi:10.5194/acp-10-3297-2010, 2010.

Neuman, J. A., Parrish, D. D., Trainer, M., Ryerson, T. B., Holloway, J. S., Nowak, J. B., Swanson, A., Flocke, F., Roberts, J. M., Brown, S. S., Stark, H., Sommariva, R., Stohl, A., Peltier, R., Weber, R., Wollny, A. G., Sueper, D. T., Hubler, G., and Fehsenfeld, F. C.: Reactive nitrogen transport and photochemistry in urban plumes over the North Atlantic Ocean, J. Geophys. Res., 111, D23S54, doi:10.1029/2005JD007010, 2006.

Owen, R. C., Cooper, O. R., Stohl, A., and Honrath, R. E.: An analysis of the mechanisms of North American pollutant transport to the central North Atlantic lower free troposphere, J. Geophys. Res., 111, D23S58, doi:10.1029/2006JD007062, 2006.

Park, R. J., Jacob, D. J., Chin, M., and Martin, R. V.: Sources of carbonaceous aerosols over the United States and implications for natural visibility, J. Geophys. Res.-Atmos., 108, 4355, doi:10.1029/2002JD003190, 2003.

Park, R. J., Jacob, D. J., Field, B. D., Yantosca, R. M., and Chin, M.: Natural and transboundary pollution influences on sulfate-nitrate-ammonium aerosols in the United States: Implications for policy, J. Geophys. Res., 109, D15204, doi:10.1029/2003JD004473, 2004.

Park, R. J., Jacob, D. J., Palmer, P. I., Clarke, A. D., Weber, R. J., Zondlo, M. A., Eisele, F. L., Bandy, A. R., Thornton, D. C., Sachse, G. W., and Bond, T. C.: Export efficiency of black carbon 
aerosol in continental outflow: global implications, J. Geophys. Res., 110, D11205, doi:10.1029/2004JD005432, 2005.

Parrish, D., Trainer, M., Holloway, J., Yee, J., Warshawsky, M., and Fehnsenfeld, F.: Relationships between ozone and carbon monoxide at surface sites in the North Atlantic region, J. Geophys. Res., 103, 13357-13376, 1998.

Parrish, D. D., Kondo, Y., Cooper, O. R., Brock, C. A., Jaffe, D. A., Trainer, M., Ogawa, T., Huübler, G., and Fehsenfeld, F. C.: Intercontinental Transport and Chemical Transformation 2002 (ITCT 2K2) and Pacific Exploration of Asian Continental Emission (PEACE) experiments: An overview of the 2002 winter and spring intensives, J. Geophys. Res., 109, D23S01, doi:10.1029/2004JD004980, 2004.

Peltier, R. E., Hecobian, A. H., Weber, R. J., Stohl, A., Atlas, E. L., Riemer, D. D., Blake, D. R., Apel, E., Campos, T., and Karl, T.: Investigating the sources and atmospheric processing of fine particles from Asia and the Northwestern United States measured during INTEX B, Atmos. Chem. Phys., 8, 1835-1853, doi:10.5194/acp-8-1835-2008, 2008.

Prospero, J. M.: Mineral and sea salt aerosol concentrations in various oceanic regions, J. Geophys. Res., 84, 725-731, 1979.

Prospero, J. M., Ginoux, P., Torres, O., Nicholson, S. E., and Gill, T. E.: Environmental characterization of global sources of atmospheric soil dust identified with the NIMBUS 7 Total Ozone Mapping Spectrometer (TOMS) absorbing aerosol product. Rev. Geophys., 40, 1002, doi:10.1029/2000RG000095, 2002.

Prospero, J. M., Savoie, D. L., and Arimoto, R.: Long-term record of nss-sulfate and nitrate in aerosols on Midway Island 19812000: evidence of increased (now decreasing?) anthropogenic emissions from Asia, J. Geophys. Res.-Atmos., 108, 4019, doi:10.1029/2001JD001524, 2003.

Rastigejev, Y., Park, R., Brenner, M. P., and Jacob, D. J.: Resolving intercontinental pollution plumes in global models of atmospheric transport, J. Geophys. Res., 115, D02302, doi:10.1029/2009JD012568, 2010.

Real, E., Pisso, I., Law, K S., Legras, B., Bousserez, N., Schlager, H., Roiger, a., and Attié, J L.: Toward a novel high-resolution modeling approach for the study of chemical evolution of pollutant plumes during long-range transport, J. Geophys. Res., 115, 1-14, doi:10.1029/2009JD011707, 2010.

Reidmiller, D. R., Jaffe, D. A., Fischer, E. V., and Finley, B.: Nitrogen oxides in the boundary layer and free troposphere at the Mt. Bachelor Observatory, Atmos. Chem. Phys., 10, 6043-6062, doi:10.5194/acp-10-6043-2010, 2010.

Remer, L. A., Kaufman, Y. J., Tanre, D., Mattoo, S., Chu, D. A., Martins, J. V., Li, R. -R., Ichoku, C., Levy, R. C., Kleidman, R. G., Eck, T. F., Vermote, E., and Holben, B. N.: The MODIS aerosol algorithm, products and validation, J. Atmos. Sci., 62, 947-973, doi:10.1175/JAS3385.1, 2005.

Remer, L. A., Kleidman, R. G., Levy, R. C., Kaufman, Y. J., Tanre, D., Mattoo, S., Martins, J. V., Ichoku, C., Koren, I., Yu, H., and Holben, B. N.: Global aerosol climatology from the MODIS satellite sensors, J. Geophys. Res., 113, D14S07, doi:10.1029/2007JD009661, 2008.

Savoie, D. L., Arimoto, R., Keene, W. C., Prospero, J. M., Duce, R. A., and Galloway, J. N.: Marine biogenic and anthropogenic contributions to non-sea-salt sulfate in the marine boundary layer over the North Atlantic Ocean, J. Geophys. Res., 107, 4356, doi:10.1029/2001JD000970, 2002.
Shao, Y. and Dong, C. H.: A review on East Asian dust storm climate, modelling and monitoring, Global Planet. Change 52, 122, doi:10.1016/j.gloplacha.2006.02.011, 2006.

Singh, H. B., Brune, W. H., Crawford, J. H., Jacob, D. J., and Russell, P. B.: Overview of the summer 2004 intercontinental chemical transport experiment - North America (INTEX-A), J. Geophys. Res., 111, D24S01, doi:10.1029/2006JD007905, 2006.

Singh, H. B., Brune, W. H., Crawford, J. H., Flocke, F., and Jacob, D. J.: Chemistry and transport of pollution over the Gulf of Mexico and the Pacific: spring 2006 INTEX-B campaign overview and first results, Atmos. Chem. Phys., 9, 2301-2318, doi:10.5194/acp-9-2301-2009, 2009.

Stohl, A.: A 1-year Lagrangian climatology of airstreams in the Northern Hemisphere troposphere and lowermost stratosphere, J. Geophys. Res., 106, 7263-7279, 2001.

Stohl, A. and Trickl, T.: A textbook example of long-range transport: Simultaneous observation of ozone maxima of stratospheric and North American origin in the free troposphere over Europe, J. Geophys. Res., 104, 30445-30462, doi:10.1029/1999JD900803, 1999.

Stohl, A., Eckhardt, S., Forster, C., James, P., and Spichtinger, N.: On the pathways and timescales of intercontinental air pollution transport, J. Geophys. Res., 107, 4684, doi:10.1029/2001JD001396, 2002.

Takemura, T., Uno, I., Nakajima, T., Higurashi, A., and Sano, I.: Modeling study of long-range transport of Asian dust and anthropogenic aerosols from East Asia, Geophys. Res. Lett., 29(24), 2158, doi:10.1029/2002GL016251, 2002.

Task Force on Hemispheric Transport of Air Pollution (TF-HTAP): Hemispheric Transport of Air Pollution 2010, Air Pollut. Stud. 17, edited by: Dentener, F., Keating, T., and Akimoto, H., UNECE, Geneva, Switzerland, available at: http://www.htap.org/, 2010.

Taubman, B. F., Hains, J. C., Thompson, A. M., Marufu, L. T., Doddridge, B. G., Stehr, J. W., Piety, C. A., and Dickerson, R. R.: Aircraft vertical profiles of trace gas and aerosol pollution over the mid-Atlantic United States: Statistics and meteorological cluster analysis, J. Geophys. Res., 111, D10S07, doi:10.1029/2005JD006196, 2006.

Thompson, A. M., Pickering, K. E., Dickerson, R. R., Ellis, W. G., Jacob, D. J., Scala, J. R., Tao, W. K., McNamara, D. P., and Simpson, J.: Convective Transport over the central United States and its role in regional CO and ozone budgets, J. Geophys. Res., 99, 18703-18711, 1994.

Tu, F. H., Thornton, D. C., Bandy, A. R., Carmichael, G. R., Tang, Y., Thornhill, K. L., Sachse, G. W., and Blake, D. R.: Long-range transport of sulfur dioxide in the central Pacific, J. Geophys. Res.-Atmos., 109, D15S08, doi:10.1029/2003JD004309, 2004.

Turquety, S., Logan, J. A., Jacob, D. J., Hudman, R. C., Leung, F. Y., Heald, C. L., Yantosca, R. M., Wu, S., Emmons, L. K., Edwards, D. P., and Sachse, G.W.: Inventory of boreal fire emissions for North America in 2004: the importance of peat burning and pyro-convective injection, J. Geophys. Res. 112, D12S03, doi:10.1029/2006JD007281, 2007.

Uematsu, M., Wang, Z., and Uno, I.: Atmospheric input of mineral dust to the western North Pacific region based on direct measurements and a regional chemical transport model, Geophys. Res. Lett., 30, 1342, doi:10.1029/2002GL016645, 2003. 
Uno, I., Amano, H., Emori, S., Kinoshita, K., Matsui, I., and Sugimoto, N.: Trans-Pacific yellow sand transport observed in April 1998: A numerical simulation, J. Geophys. Res., 106, 1833118344, 2001.

Uno, I., Yumimoto, K., Shimizu, A., Hara, Y., Sugimoto, N., Wang, Z., Liu, Z., and Winker, D. M.: 3-D Structure of Asian Dust Transport revealed by CALIPSO Lidar and a 4DVAR Dust Model, Geophys. Res. Lett., 35, L06803, doi:10.1029/2007GL032329, 2008.

van der Werf, G. R., Randerson, J. T., Giglio, L., Collatz, G. J., Kasibhatla, P. S., and Arellano Jr., A. F.: Interannual variability in global biomass burning emissions from 1997 to 2004, Atmos. Chem. Phys., 6, 3423-3441, doi:10.5194/acp-6-3423-2006, 2006.

VanCuren, R. A.: Asian aerosols in North America: Extracting the chemical composition and mass concentration of the Asian continental aerosol plume from long-term aerosol records in the western United States, J. Geophys. Res., 108, 4623, doi:10.1029/2003JD003459, 2003

van Donkelaar, A., Martin, R. V., Leaitch, W. R., Macdonald, A. M., Walker, T. W., Streets, D. G., Zhang, Q., Dunlea, E. J., Jimenez, J. L., Dibb, J. E., Huey, L. G., Weber, R., and Andreae, M. O.: Analysis of aircraft and satellite measurements from the Intercontinental Chemical Transport Experiment (INTEX-B) to quantify long-range transport of East Asian sulfur to Canada, Atmos. Chem. Phys., 8, 2999-3014, doi:10.5194/acp-8-2999-2008, 2008.

Wandinger, U., Mattis, I., Tesche, M., Ansmann, A., Bösenberg, J., Chaikovski, A., Freudenthaler, V., Komguem, L., Linné, H., Matthias, V., Pelon, J., Sauvage, L., Sobolewski, P., Vaughan, G., and Wiegner, M.: Air mass modification over Europe: EARLINET aerosol observations from Wales to Belarus, J. Geophys., Res., 109, D24205, doi:10.1029/2004JD005142, 2004.

Wang, Y., Jacob, D. J., and Logan, J. A.: Global simulation of tropospheric $\mathrm{O}_{3}-\mathrm{NO}_{\mathrm{x}}$-hydrocarbon chemistry 1 . Model formulation, J. Geophys., Res., 103, 10713-10725, 1998.

Warneke, C., de Gouw, J. A., Del Negro, L., Brioude, J., McKeen, S., Stark, H., Kuster, W. C., Goldan, P. D., Trainer, M., Fehsenfeld, F. C., Wiedinmyer, C., Guenther, A. B., Hansel, A., Wisthaler, A., Atlas, E., Holloway, J. S., Ryerson, T. B., Peischl, J., Huey, L. G., and Hanks, A. T. C.: Biogenic emission measurement and inventories determination of biogenic emissions in the eastern United States and Texas and comparison with biogenic emission inventories, J. Geophys. Res., 115, D00F18, doi:10.1029/2009JD012445, 2010.

Wesley, M. L.: Parameterization of surface resistance to gaseous dry deposition in regional numerical models, Atmos. Environ., 16, 1293-1304, 1989.

Wuebbles, D. J., Lei, H., and Lin, J. T.: Intercontinental transport of aerosols and photochemical oxidants from Asia and its consequences, Environ. Pollut., 150, 65-84, doi:10.1016/j.envpol.2007.06.066, 2007.

Yienger, J. J., Galanter, M., Holloway, T. A., Phadnis, M. J., Guttikunda, S. K., Carmichael, G. R., Moxim, W. J., and Levy, H.: The episodic nature of air pollution transport from Asia to North America, J. Geophys. Res., 105, 26931-26945, 2000.

Yu, H., Remer, L. A., Chin, M., Bian, H., Kleidman, R. G., and Diehl T.: A satellite-based assessment of transpacific transport of pollution aerosol, J. Geophys. Res., 113, D14S12, doi:10.1029/2007JD009349, 2008.

Yu, H., Remer, L. A., Chin, M., Bian, H., Tan, Q., Yuan, T., and Zhang, Y,: Aerosols from Overseas Rival Domestic Emissions over North America, Science, 337, 566-569, doi:10.1126/science.1217576, 2012.

Zhang, J. and Reid, J. S.: MODIS aerosol product analysis for data assimilation: Assessment of over-ocean level 2 aerosol optical thickness retrievals, J. Geophys. Res., 111, D22207, doi:10.1029/2005JD006898, 2006.

Zhang, J., Reid, J. S., and Holben, B. N.: An analysis of potential cloud artifacts in MODIS over ocean aerosol optical thickness products, Geophys. Res. Lett., 32, L15803, doi:10.1029/2005GL023254, 2005.

Zhang, L., Gong, S., Padro, J., and Barrie, L. A.: A size-segregated particle dry deposition scheme for an atmospheric aerosol module, Atmos. Environ., 35, 549-560, 2001.

Zhang, Q., Streets, D. G., Carmichael, G. R., He, K. B., Huo, H., Kannari, A., Klimont, Z., Park, I. S., Reddy, S., Fu, J. S., Chen, D., Duan, L., Lei, Y., Wang, L. T., and Yao, Z. L.: Asian emissions in 2006 for the NASA INTEX-B mission, Atmos. Chem. Phys., 9, 5131-5153, doi:10.5194/acp-9-5131-2009, 2009. 